\title{
Experience in California with Fair Trade Legislation Restricting Price Cutting
}

\begin{abstract}
CAIIFORNIA has two statutes which are intended to provide the basis
for setting bounds to price cutting, especially in the retail trades, and which are commonly classified as "fair trade legislation." These two statutes, unfortunately, are frequently confused, partly because of similarity of title, more likely because they operate in the same general area. However, these laws are decidedly different in procedure and in their effects and range of application.

The better known of the two is the Fair Trade Law, passed in 1931 and amended in 1933. ${ }^{1}$ It is this statute which was the pattern for other states in 1935 and since; so much so that by the end of 1935 nine other states had passed laws identical with or modelled closely upon the California Act. It appears at this writing that a small number of additional states will have followed the California lead by the end of $1936 .^{2}$ The 1935 states, with California, comprised forty per cent of the population of the United States.

The other law is the Unfair Practices Act of $1935 .^{3}$ Although it has not aroused as much interest as yet, there is considerable evidence that this interest is rising. Whereas the Fair Trade Law has to do with vertical price relations, the Unfair Practices Act operates horizontally. Thus in a sense, these statutes are supplementary as will be noted in the detailed discussion to follow.

The purpose of this paper is fourfold: (1) to state briefly the legal history of these two types of legislation in California; (2) to describe the experience to date in California; (3) to indicate the possible range of application in the various classes of business; and (4) to evaluate
\end{abstract}

1 Cal. Stats. 1931 , p. 583 ; Cal. Stats. 1933, p. 793.

2 The chronological 1935 list is as follows: New Jersey, Oregon, Washington, Iowa, Maryland, New York, Wisconsin, Pennsylvania, Illinois. These laws, except for Hlinois, Washington, and Wisconsin are in effect identical. The differences in the acts of the above three states are only slight. The Illinois law provides for a ten day notice before sale under the exceptions noted to the provisions of the Act. The Washington law was passed as an emergency measure and expires July, 1937. The Wisconsin law is unique in that it provides a basis for the review of prices established under contract upon complaint. For greater detail, as well as for an excellent and convenient summary see Kantor \& Golden, Resale Price Manvtenance Legislation IN the UnIted States (1935), Work Materials No. 16, Division of Review, National Recovery Administration, p. 116. As this article goes to press, trade journals report that the governor of Louisiana has signed the fair trade bill passed by the Louisiana legislature, thus bringing the number of states with fair trade statutes to fourteen. At this writing the writer has not seen these 1936 hills and is unahle to state whether they are identical with the California statute.

3 Cal. Stats. 1935, pp. 1546-1551. 
the economic consequences of the activity under the acts. Interpretation of the law, techincally speaking, will not be attempted in this paper. However, much of the data presented here assists in the evaluation of the various legal bases of this type of restrictive legislation. ${ }^{4}$

\section{THE FAIR TRADE LAW}

The 1931 Fair Trade Law is entitled "An Act to protect trade mark owners, distributors and the public against injurious and uneconomic practices in the distribution of articles of standard quality under a distinguished trade inark, brand or name." The essence of the act is that it makes contracts between producers and owners of identified commodities and their distributors with respect to resale price lawful. That is, it legalizes resale price control under contract in California when the commodities are sold in "fair and open competition with commodities of the same general class." It should be noted that the specific wording of the resale price provision is "that the buyer will not resell such commodity except at the price stipulated by the vendor." " It is interesting that the majority of contracts employed in the state establish minimum, not fixed prices. The act in its 1931 forn was merely a permissive statute of a voluntary nature and gave no rights or powers except when contracts were involved. Exceptions to the contractual provisions were stated in the act: (1) in the case of "closing out . . . stock for the purpose of discontinuing delivering any such commodity," (2) when goods were damaged or deteriorated in quality and notice to that effect was given the public, and (3) when goods were sold by an officer acting under the laws of any court. The vertical nature of the rights under the act are clearly indicated by Section 2: "This act shall not apply to any contract or agreement between producers or between wholesalers or between retailers as to sale or resale prices." 6

4 The writer wishes to stress the fact that this discussion is not intended to be definitive or final. On some aspects of the problem he still has further research under way. Moreover, after the general introduction, the detailed analysis will be confined only to the grocery and drug trades, although there is much material collected for other lines. Further, within these two trades, complete supporting summaries of data will not always be employed because of lack of space. The writer plans within a year to publish a larger review of the problem in book form. In this paper the writer is heavily indebted to the collection of material which he presented in MERRELI, Grether \& Kittelie, Restriction of Retall Price Cutting With Emphasis on THE Drug Industry (1936), Work Materials No. 57, Division of Review, National Recovery Administration.

5 Cal. Stats. 1931, p. 583. Itahics are the writer's.

6 The California Act has often been called "The Junior Capper-Kelly Bill" because it was the intra-state expression of the federal Capper-Kelly bill which passed the House of Representatives in 1931 and then failed to reach a vote in the Senate. From this point on the interest in this type of law shifted heavily towards obtaining favorable state legislation. 
THE LAW PRIOR TO NINETEEN THIRTY-ONE IN CALIFORNIA

Under the wording of the Cartwright Act of 1907 price maintenance in California was unlawful. The Cartwright Act, which is the anti-trust law of the state, defined a "trust" and provided for criminal penalties and civil damages, and punishment of corporations, persons, firms, and associations involved in trust agreements. The Act enumerated a number of arrangements among members of the trade which were specifically prohibited as of the quality of trusts. Among these was one which prohibited the fixing of any standard or figure, whereby price to the public shall be controlled, and another, nnaking or entering into or executing or carrying out any contracts, obligations or agreements of any kind or description, binding the parties not to sell an article of trade below a common standard figure or $\mathrm{m}$ any way keeping the price at a fixed or graduated figure. ${ }^{\top}$

However, in 1909, the Cartwright Act was amended as follows: ${ }^{8}$

"Sec. 1. Every such trust as is defined herein is declared to be unlawful, against public policy and void, provided that no agreement, combination or association slrall be deemed to be unlawful or witlin the provisions of this act, the object and business of which are to conduct its operations at a reasonable profit or to market at a reasonable profit those products which cannot otherwise be so marketed; provided further, that it shall not be deemed to be unlawful, or within the provisions of this act, for persons, firms or corporations, engaged in the business of selling or manufacturing commodities of a similar or like character, to employ, form, organize or own any interest in any association, firm or corporation, having as its object or purpose the transportation, marketing or delivery of such commodities.

"Sec. $2 \pi / 2$. It shall be lawful to enter into agreements or form associations or combinations, the purpose and effect of which shall be to promote, encourage or increase competition in any trade or industry, or which are in the furtherance of trade."

Following this amendment the supreme court of the state held that a manufacturer has the right to fix the resale price of his products in two leading cases. The first case was Grogan v. Chaffee in 1909. Chaffee, the defendant, a retailer ni Pasadena, had purchased olive oil from the planitiff under an express contract not to sell it below the price established by Grogan. Chaffee held the contract in restraint of trade and refused to abide by its terms. In the opinion the supreme court declared: ${ }^{9}$

".... There is nothing either unreasonable or unlawful in the effort by a manufacturer to maintain a standard price for bis goods. It is simply a means of securing the legitimate benefits of the reputation which his product may lave attained."

The second case was Ghirardelli v. Hunsicker in 1912. This case is peculiarly siguificant because it involved a wholesale intermediary

7 Cal. Stats. 1907, pp. 984-7.

8 Cal. Stats. 1909, p. 594.

9 (1909) 156 Cal. 611, 614, 105 Pac. 745, 747. 
between the manufacturer and the retailer. Hunsicker, a retailer, had purchased Ghirardelli chocolate from a wholesaler. The Ghirardelli Company at the time attached a label to its product with the following notice:

\section{"IMPORTANT NOTICE.}

"The grades contained in this case are sold on the express condition, made a part of the consideration of the sale, whether same is made by the manufacturer or wholesaler, that the purchaser, if he retails them, will maintain our fixed retail price on these goods, and if he wholesales them he will do so subject to the same condition. The acceptance of these goods is an agreement .... not to retail them, under any circumstances for less than the estahlished price.

"Our fixed minimun retail price on Ghirardelli's Ground Chocolate for the Pacific Coast is $30 \%$ per $1 \mathrm{lb}$. tins and $80 \&$ for $3 \mathrm{lb}$. tins.

(Signed) D. Ghirardelli Company."

Hunsicker, the defendant, had full knowledge of this notice and purchased under this agreement, yet sold at prices below those stipulated. Hunsicker claimed that the Ghirardelli Company could not force him to maintain its prices because he did not deal with them directly. The Supreme Court, however, held otherwise, stating that a contract made expressly for the benefit of a third person may be enforced by hin under Section 1559 of the Civil Code, provided the contract is enforceable. The Court held also that this particular form of agreement was not unenforceable under the common law or the Sherman Anti-Trust Act; likewise that it did not violate the Cartwright Act of the State since its object was to enable the manufacturer to conduct his business at a reasonable profit. ${ }^{10}$

Thus, following the 1909 Amendunent to the Cartwright Act ${ }^{11}$ resale price maintenance was lawful in California under the decisions of the supreme court. The passage of the 1931 Act $^{12}$ not only put the law into statutory form but raised a safeguard against a potential United States Supreme Court threat following the decision in the case of Cline v. Frink Dairy Co. ${ }^{13}$

10 (1912) 164 Cal. 355, 128 Pac. 1041.

It is interesting to note the interpretation of the British Courts with respect to the rights of third parties to a contract in a case somewhat similar. In the case of Dunlop Pneumatic Tyre Co. v. Selfridge \& Co. (1915) K.B. 1680, it was held that a manufacturer may have a right of action against a contracting wholesaler, but not against a sub-purchaser, even though he had contracted with the wholesaler. The action would be with the wholesaler as the contracting party. In this case, however, there is the difference that the product did not contain the notice of the conditions of sale as in the Ghiradelli case, although the defendant had contracted with the wholesaler. For further details, see GretHer, Resale PrICE MaInTENance In GREAT BRITAIN (1935) 260.

11 Supra note 8.

12 Supra note 5.

13 (1927) 274 U. S. 445. 


\section{THE NINETEEN THIRTY-THREE AMENDMENT}

In 1933 the legislature added a section to the 1931 law as follows:

"Wilfully and knowingly advertising, offering for sale or selling any commodity at less than the price stipulated in any contract entered into pursuant to the provision of section 1 of this act, whether the person so advertising, offering for sale or selling is or is not a party to such contract, is unfair competition and is actionable at the suit of any person damaged thereby." 14

It is this amendment which has put the vitality into the statute and which has been copied in other states. The amendment makes the contractual prices binding even upon non-contractors when there is evidence that the non-contracting third party has been informed of the contractual prices. To a layman at least, it appears that the effect of this provision is to make control "run with the goods." It should be noted that selling below the contractual price is actionable "at the suit of any person damaged thereby," not merely on the part of the manufacturer. The reasons for the passage of the 1933 amendment will be discussed in detail below; here it need merely be stated that its purpose was to introduce the coercive element essential to any large scale attempt to employ the Act. The effect of the amendment was not only to produce a tremendous increase in resale price control activity but to arouse a great amount of legal testimg in the California courts.

The writer has not obtained a complete record of all the cases that have appeared in the California courts. By November 1935, thirty-one cases were known to him; and a considerable number reached decision after that time and before the supreme court decision, February 27, $1936 . .^{15}$ In addition, a considerable number had been settled out of court. The great majority of the superior court cases were favorable. There were two leading early denials in the cases of Max Factor \& Co. and Sales Builders, Inc. v. Kunsman ${ }^{16}$ and Pyroil Sales Co. v. the Pep Boys, Manny, Moe and Jack of California. ${ }^{17}$ These two cases were carried to the state supreme court and are to be reviewed by the United States Supreme Court in October of this year. The California supreme court handed down a favorable decision in the Max Factor case, ${ }^{18}$ February 27,1936 , by a four to two vote. A separate decision was not made for the Pyroil case because the facts and questions mvolved were identical with those of the Max Factor case. In the superior courts and before the supreme court the issue primarily was the 1933 amendment to the Act. ${ }^{19}$

\footnotetext{
14 Supra note 1.

15 Infra note 18.

${ }^{16} \mathrm{~L}$. A. No. 14662.

17 L. A. No. 14954.

18 Factor v. Kunsman (1936) 91 Cal. Dec. 345, 55 P. (2d) 177; petition for rehearing denied Mar. 26, 1936.

19 Supra note 1.
} 
Only a brief review of the facts and conclusions of the Max Factor case is included in this paper. Max Factor \& Co., a Delaware corporation, engaged in the manufacture of cosinetics and toilet articles sold under certain adopted and registered trade marks, had transferred to Sales Builders, Inc. the exclusive right and privilege of distributing and selling its cosmetics and toilet articles in the United States, including the State of California. Sales Builders, Inc. had issued contracts covering resale prices on Max Factor products in California. The bulk of wholesale and retail distributors had signed these contracts. The defendant, who owned and operated a drug store in Beverly Hills, refused to sign a contract when tendered or to conform to the system of distribution set up by Sales Builders, Inc. The defendant obtained Max Factor products through unknown channels and continued to sell them at prices below those of the majority of dealers in California and in violation of the schedule of the plaintiff. Further, the action of Kunsman in cutting prices and informing other dealers and the public of his intention to continue to do so, led other wholesale and retail distributors to complain that they would be compelled to cancel their contracts and to meet the prices of the defendant. This state of affairs, it was alleged, was destructive of the business and of the goodwill of the plaintiffs. The plaintiffs held that the continuance of these acts would produce great and irreparable injury, but that it would be extremely difficult, if not impossible, to ascertain the amount of damage; hence, equitable relief by way of injunction was sought. The supreme court reversed the order of Judge Wilson, thus declaring that in California the 1933 amendment was constitutional.

THE UNFAIR PRACTICES ACT

The Unfair Practices Act of 1935 represented the culmination of legislation begnn in 1913. On August 10, 1913, there went into effect an act "relating to unfair competition and discrimination," entitled the "Unfair Competition Act." 20 The core of this act was a provision declaring it unlawful to discriminate between different sections, communities, cities or between different locations in the state by selling at a lower rate than justified by quality, quantity or cost differences "with the intent to destroy the competition of any regular established dealer." 21 As far as the writer has been able to discover this statute lay practically dormant until 1931 when it was resurrected and amended. The original statute had its prime significance in the public utility field; the 1931 statute was directed primarily at large scale distributors, especially chain store systems. The 1931 amended statute was called the Anti-Discrimination Act.

20 Cal. Stats. 1913, pp. 508-510.

21 Italics added. 
Chiefly it reiterated the 1913 provisions, made slight modifications in the anti-discrimination provision and provided additional penalties. ${ }^{22}$

In 1933 two other significant amendments were added. In the one it is stated that the secret payment or allowance of rebates, refunds or commissions, or unearned discounts, whether in the form of money or otherwise, or secretly extending to certain purchasers special services or privileges not extended to all purchasers purchasing upon like terms and conditions, to the mjury of a competitor and where such payment or allowance tends to destroy competition is an unfair trade practice. ${ }^{23}$ The second amendment was much more significant and was known as the Sales Below Cost Act. ${ }^{24}$ Its leading provision prohibited sales below cost or the giving away of an article or product "for the purpose of injuring competitors and destroying competition." Cost in the field of production was defined as "including the cost of raw materials, labor and all necessary overhead expenses of the producer;" in the field of distribution it was defined as the cost "to the distributor or vendor plus the cost of doimg business by said distributor and vendor."

The 1913 act with its 1931 and 1933 amendments was again resurrected in 1935 and now became the lengthy and well-known Unfair Practices Act. ${ }^{25}$ The 1935 act reiterates the earlier anti-discrimination provisions as well as the prohibition of secret payments, allowances, etc. Its most significant modifications have to do with the sales below cost provision. In reiterating the prohibition of sales below cost, two significant additions were made. First, costs were defined more closely. As applied to production, cost was defined "as including the cost of raw materials, labor, and all overhead expenses of the producer." As applied to distribution, cost was defined as "invoice or replacement cost, whichever is lower ... . plus the cost of doing business." Then the "cost of doing business" or "overhead expense" was defined "as all costs of doing business incurred in the conduct of such business and must include without limitation the following items of expense: labor (including salaries of executives and officers), rent, interest on borrowed capital, depreciation, selling cost, maintenance of equipment, delivery costs, credit losses, all types of licenses, taxes, insurance and advertising." Second, there was a provision that "Where a particular trade or industry, of which the person, firm or corporation coinplained agamst is a member, has an established cost survey for the locality and vicinity in which the

22 Cal. Stats. 1931, pp. 1333-5.

23 Cal. Stats. 1933, p. 793.

24 Cal. Stats. 1933, pp. 1280-1.

25 Supra note 3 . It should be noted that all of the prohibitions are limited as in the earier acts to situations where the intent is "to prevent competition" (Section 1) or is "for the purpose of injuring and destroying competition" (Section 3). 
offense is committed, the said cost survey shall be deemed competent evidence to be used in proving the costs of the person, firm or corporation complamed against withm the provisions of this act." ${ }^{26}$ In establishing cost, lowever, invoice cost at forced, bankrupt or closeout sales, or other sales outside the ordinary channels of trade may not be used as a basis for justifying a price lower than replacement cost through the ordimary channels "unless said article or product is kept separate froin goods purchased in the ordinary channels of trade and unless said article or product is advertised and sold as inerchandise purchased at a forced, bankrupt, closeout sale, or by means other than through the ordinary channels of trade, and said advertising shall state the conditions under which said goods were so purchased, and the quantity of such merchandise to be sold or offered for sale." $2 \pi$

Four exceptions are made to the sales below cost prohibition:

(1) In a bona fide closing out sale, and in the sale of seasonal and perishable goods to prevent loss by spoilage and depreciation.

(2) In the sale of deteriorated goods when notice thereof is given to the public.

(3) In the sale by an officer acting under the orders of a court.

(4) It is lawful "to meet the legal prices of a coinpetitor" in the saine locality or trade area.

The latter exception is particularly important as will be noticed below when the possibilities under the act are discussed.

One other innovation of the 1935 act is peculiarly significant. In Section 10 it is stated: "Any person, frrm, private corporation, or municipal or other public corporation, or trade association, may maintain an action to enjoin a continuance of any act or acts in violation of sections 1 to 7 , inclusive, of this act, and, if imjured thereby, for the recovery of damages." It was under this section that it was planned to organize and police the trades under their respective trade associations in California in a manner similar in kind to the N.R.A. code procedure.

So much for the legal background of the problem. Both the Fair Trade Law and the Unfair Practices Act will be examined below in the light of experience under them in the state as well as in relation to their specific provisions and inherent qualities.

THE POLITICAL PRESSURE FOR FAIR TRADE IEGISLATION

The influential political forces behind the legislative devices outlined in the preceding sections have been the various retail associations of the State of California aided by the jobbers, especially in the drug trade.

\footnotetext{
20 Supra note $3, \S 5$.

$2 \pi$ Ibid., \& 4.
} 
Within the state there are some of the most cohesive and powerful retail organizations in the country, headed by aggressive, able officers, particularly executive secretaries. The smaller independent merchants have developed a class consciousness out of which has arisen effective direct political action. This attitude of mind shows itself in other directions as in the large, long established, powerful, cooperative buying and merchandising groups. In San Francisco, for instance, there are two voluntary merchandising groups in the grocery trade that date back to the first decade of the century. It has been interesting to note that after each legislative triumpl the officers of various retail associations have taken individual credit for the enactment. However, the center of the battle and the stress varied between lines. The Fair Trade Act ${ }^{28}$ was nurtured in the Southern and Northern California Retail Druggists' Association (particularly in the office of the southern association) and the center of interest and of the legislative battle was in these two groups. The jobbing interests in the drug trade were also aggressively pushing the Act. The state of affairs is as one should expect, for the retail and wholesale druggists have more to gain from resale price maintenance legislation than the majority of trades. In this instance, some of the chains were also partisans of the legislation, apparently because the newer cut-rate types were removing much of the chains' former advantage gained by price cutting tactics. On the other hand the grocery chains were definitely opposed to the Unfair Practices Act. ${ }^{20}$ The center of the endeavor in this instance appears to have been in the grocery business, with the close cooperation of other retail groups.

To appreciate the legislative background it is also essential to note that these statutes were promulgated during depression years. Both the vigor of the demands and the weakness of opposition were decidedly tempered by the conditions of the glutted market. The impact upon the legislature showed itself not only in the fair trade acts, but in a great number of measures aimed at economic control. Apparently, legislators had accepted the proposition that price cutting in the distributive trades engenders a series of repercussions that react harmfully upon primary producers. $^{30}$

This doctrine is clearly shown in the Unfair Practices Act ${ }^{31}$ which is declared an urgency measure "for the immediate preservation of the public peace, health and safety," and ends with the statement that "The

28 Supra note 1.

20 Supra note 3.

30 This dogma was written into the master retail code of the N.R.A. and is echoed time and again in court opinions. Also it was accepted in connection with the marketing agreement acts.

31 Supra note 3. 
sale at less than cost of goods obtained at forced, bankrupt, closeout, and other sales outside of the ordinary channels of trade is destroying healthy competition and thereby forestalling recovery. If such practices are not immediately stopped many more businesses will be forced into bankruptcy, thus increasing the prevailing condition of depression."

It would be a mistake to interpret the cry for resale price maintenance legislation merely as a depression phenomenon, for resale price maintenance agitation runs back into the end of the last century. Since 1914 each session of Congress has had one or more bills before it to legalize price control in some form..$^{32}$ The phenomenon has been as prevalent in foreign industrialized countries as in the United States. ${ }^{33}$

However, the vigor of the demands in the last few years and the adoption and acceptance of the 1933 amendment appear indubitably linked to the economic pressure of the years in the trough of the depression. It is to be hoped that we may soon discover the effects of full prosperity both upon the theories of jurists and the attitudes of business.

EXPERIENCE IN THE GROCERY TRADE WITH RESALE PRICE MAINTENANCE

The grocery trade affords an excellent laboratory in which to study the impact of fair trade legislation for (1) it is the dominant consumers' goods trade, (2) it has officially, aggressively sponsored both of the bills, (3) the results are sufficiently mature and clear cut to provide a basis for sound generalization.

The official associations in the grocery trade have been active sponsors of the Fair Trade Act. ${ }^{34}$ At the annual conventions, in local meetings, in speeches of the secretaries, in the official publications, are found numerous references to the Fair Trade Act. The California Retail Grocers and Merchants Association listed the 1931 law and the 1933 amendment among its legislative achievements. Yet there has been only a negligible amount of activity under the Fair Trade Act to date; it is the writer's opinion that this type of procedure inherently cannot have wide application in the food trades.

In the past few years there have been three general resale price maintenance procedures in the grocery trade. First, a number of manufacturers suggest or recommend resale prices but make no particular effort at enforcement, except, perhaps, occasionally trying to adjust a bad situation by educational and persuasive methods or by refusal to sell. Second, a small number of manufacturers and distributors have

\footnotetext{
32 See Seligajan \& Love, Price Cutiting and Price Maintenance (1932) 479-84 for a brief tabular digest of the provisions of the principal bills.

33 See Seltgman \& Love, op. cit. supra note 32, Appendix IV; and GreTher, op. cit. supra note 10 .

34 Supra note 1.
} 
established so-called "stop" prices which usually provide small margins but are not protected by contracts under the Fair Trade Act. Third, there has been a very slight amount of operation under the Fair Trade Act through the issuance of contracts.

The establishing of minimum resale prices of a formal variety under the "stop loss" procedure mentioned above has been pushed by the officers of the state association, but has not to date become of great consequence. Such stop price procedure might take place under the California Fair Trade Act through the issuance of contracts; actually, one must comb the trade very closely to find any evidence at all of such usage. It became the custom of the California Retail Grocers' Advocate, organ of the California Retail Grocers and Merchants Association, to publish a list of the brands maintaining a stop price. Eventually two lists were published; one, of brands maintaining a stop price without the use of contracts, the other of firms issuing contracts. On August 12, 1932, the non-contract list contained 36 items (including different sizes) and fourteen firms. By September 15, 1933 this list had expanded to 120 items and 42 firms. Gradually, however, this listing decreased in numbers until in 1935 it gave way to a list of minimum prices suggested under the Unfair Practices Act. On April 20, 1934 the contract list contained 29 items and six firuns. However, only one of these firms, a coffee roaster, was a grocery manufacturer, the others were wine and liquor firms. Throughout the 1934 period of listing, only three regular grocery items appeared; viz., two coffees and a nut margarine. On April 17, 1936, The California Retail Grocers' Advocate began again to publish weekly a list of items under contract. By the end of May the listing contained only 51 items (including different sizes) sold by six firms. These six firms were in the following types of business: soft drinks, liquor, egg, soap, bird seed, and dog food. ${ }^{35}$ In other words, Fair Trade contracts to date have had significance to the grocery trade in California only in a few instances, and primarily in lines falling outside the field of groceries.

\section{RETAIL EXPERIENCE AND ATTITUDES}

During the summer of 1934 one hundred retail grocers in the San Francisco Bay region were interviewed to discover their experience with and attitudes toward resale price maintenance. It was found that the general run of grocery retailers have not had sufficient experience with serious price maintenance schemes to make possible any significant generalization. However, two conclusions may be derived from this lack of experience: (1) the majority of retail grocers in the summer of 1934

35 California Retail Grocers' Advocate, May 29, 1936, p. 24. 
were unaware of the existence of the California Fair Trade Act. ${ }^{36}$ To be exact, 57 out of the 100 retail grocers interviewed in the San Francisco Bay region were coinpletely uninformed concerning the law. This was an interesting contrast to the drug field where all dealers were thoroughly informed concernimg the law. (2) The majority of retail grocers had made no effort to further resale price maintenance. Eighty-nine per cent of those interviewed stated that they had given no support at all to the movement, either by donations to the legislative fund or by participating with the retail associations. Through featuring or pushing their products only twenty-one per cent gave any evidence of offering to cooperate with manufacturers who attempted to control resale prices. However, as a matter of business principle, the great majority were definitely in favor of resale price maintenance (ninety-one per cent so expressed themselves). The majority opinion was that such a program would be excellent, but that it was impossible of achievernent in this field. It should be noted that the above conclusions are derived from interviews from a non-selective list of dealers; a selected list of active members of one of the grocers' associations would without doubt, show a different, but less representative result.

The larger chains and the smaller ones that feature cut prices expressed themselves definitely in opposition to price maintenance; the voluntary chains were in favor of price maintenance.

\section{EXPERIENCE AND ATTITUDES OF MANUFACTURERS AND DISTRIBUTORS}

In the fall of 1934 one hundred and ninety manufacturers and distributors in the San Francisco area were interviewed. ${ }^{37}$ Forty-six of these firms were in the food field. Twenty-nine of the forty-six stated that they made no pretense of suggesting resale prices. Seventeen were recommending resale prices, but only five firms were at all attempting to enforce their price schedules and none of these had issued contracts. Interestingly enough, twenty-nine firms expressed themselves in favor of resale price control and only five were definitely in opposition, while the balance were apathetic and had no clear-cut opinion on the matter. In addition to the five firms which were at the time making some attempt at retail price stabilization there were nine firms that had had previous experience. Seventeen of the forty-six felt that retail price cutting was inimical to their interests; the balance thought it was immaterial or advantageous.

36 Supra note 1.

37 During 1934 the interviewers were relief workers and usually were capable merely of routine field work. Following that period the writer is highly indebted to Lorenzo A. McHenry, graduate student of the University of California, for assistance in field work. 
During January and July of 1935 thirty-nine manufacturers and distributors of food products were interviewed in Los Angeles. In this survey, nost of the firms were selected because it was known that they had bad some experience with resale price control or because they were in a dominant trade position. Of the thirty-nine firms, twenty-two stated that they were recommending resale prices; of the twenty-two, only eight were making any attempt at enforcement. Twenty-one of the thirty-nine firms expressed themselves favorably towards resale price control; twelve were in opposition and six had no opinion. Ten firms stated that price cutting in the retail trades injured them; two said they benefited by it and the balance felt it was immaterial. One firm in the group was employing Fair Trade contracts; another had done so but had discontinued the practice. Nine firms had had extensive experience at attempting to control resale prices; six of these felt such a scheme was feasible and three were dubious. Among the firms that had attempted resale price stabilization there was considerable complaint that dealers did not appreciate their efforts and that competitors gained at their expense. ${ }^{38}$

RESISTANCES TO RESALE PRICE CONTROL IN THE GROCERY TRADE

On the basis of evidence collected from the interviews with the retail dealers and inanufacturers and distributors and $a$ priori reasoning, it is possible to indicate a considerable number of resistances to resale price control in the distribution of food products. Many of the resistances are potentially ephemeral and hence subject to modification or removal; others are deeply rooted and act as permanent barriers to large-scale activity under the Fair Trade Act. Among the resistances to date that may be merely of a temporary nature, the following should be noted:

1. Until recently there was a tremendous lack of knowledge concerning the law in the trade in general.

2. Among those who were familiar with the law there was a widespread belief that it was unconstitutional and hence it was not considered worth while to set up a procedure under it.

3. During the period of the N.R.A. code several manufacturers who had attempted some amount of resale price control passed the burden over to the code authorities. In the more recent period, the same attitude is expressed toward the Unfair Practices Act; i.e., it is felt that retailers can obtain all the protection and stabilization needed under this latter act.

4. There has been no well organized group effort among either retailers or their suppliers to cooperate under the Act. An essential part of an

38 For detailed account of the experience and attitudes of fourteen selected firms see MERREIL, GRETHER \& KTTTELIE, op. cit. supra note 4, at 221-225. 
effective demand for resale price control is the organized coercive influence of the retail interests. This influence has been lacking to date in California. ${ }^{39}$ Likewise, among manufacturers and distributors, effective resale price control requires cooperation anong those in the same product class. The experience of the trade has been that a firm which proceeds alone assumes a tremendous risk. To date there have been only sporadic and weak efforts at cooperation. ${ }^{40}$

5. Without doubt there have been leadership difficulties. To a very great extent movements of this sort derive their vigor from the quality of the leadership available in the trade. The food trades do not lack leadership; but it has been directed into other channels such as the antichain store movement and stabilization under the Unfair Practices Act.

6. The unsatisfactory past experience of a number of manufacturers lingers as a restraining influence.

7. The difficulties of operation under state law deter not only interstate sellers but local firms, because of the frequent impossibility of closing out-of-state sources of supply to price cutters, as well as the conflict of federal and state law.

8. In the grocery trade there is the deeply rooted practice of featuring "specials." Well known, advertised brands make excellent specials, and without doubt manufacturers often gain from having their products thus used. Hence, there is considerable resistance to removing the base of this type of selling.

All of the above resistances are subject to manipulation, if not to complete control. However, there are more permanent resisting infiuences. In the first place there is the inherent nature of many food products. Many food products must be sold under conditions of relatively flexible price adjustments. These adjustments may be traceable to perishability, to the close short run dependence of retail prices upon prices in the primary markets, to changes in freight rates or to other insistent, immediate factors. The fact that foods bulk so highly in the consumer's scheme of thimgs makes price an extraordinarily important element determining purchase; hence, there is great pressure from consumers upon dealers. Frequently, seasonal factors enforce short run price adjustments. For those items in which short run price flexibility is essential, it is exceedingly difficult, if not impossible, to operate a system of price maintenance. A significant factor influencing the above considerations is the fact that raw material and factory costs of food production constitute a much larger proportion of selling price than in the case of some commodities, for example, drugs.

39 On the contrary it has been the essence of the success in the drug trade discussed infra.

40 The best examples are in the sale of coffee and mayonnaise. 
In the second place, there are large numbers of retailers, manufacturers and wholesale distributors involved in the trade. There is very intimate relation, other factors being equal, between the relative numbers in a trade and the interest in, and feasibility of price maintenance. Both the grocery trade and the tobacco trade are made up of a large number of outlets. Consequently the problems of policing dealers and that of obtaining and maintaining cooperation among competitive suppliers in the same commodity class are exceedingly difficult of solution.

In the third place, there is the closely related element of the relative complexity of the trade. Complexity is a factor of: (1) the variety in the structure of the trade; (2) the variety of products; (3) the degree of indirect selling; (4) the extent of inter-outlet competition. All of these factors complicate the grocery field. The structure of the trade in the retail busimess contains tremendous variety, including small specialists, general stores, chain stores, cooperative groups, voluntary chains, department stores, super-markets, large institutional buyers, eating places and miscellaneous types as well as wide qualitative differences within each type. A similar condition exists in the wholesale trade, except that a general tendency toward direct selling in recent years has tended to simplify the channels of distribution. The wholesale business, however, is extraordmarily complicated by variations of type and by contractual relations ${ }^{41}$ of a variable quality. The general trend toward direct selling, although it has simplified the labyrinth of distribution, has not similarly simplified the problem of price maintenance insofar as it has arisen out of the chain store growth, for these organizations usually resist price control. It is needless to over-stress the obvious variety of products in the food field. The prime difficulty from the standpoint of price maintenance is: (1) the lack of trade marking and branding for many food commodities of a staple quality, allowing these non-branded items to be used as "loss leaders" in case the nationally advertised lines become controlled; (2) the large number of private brands and the general ease of access to unidentified merchandise for private label purposes. Consequently, the effects of resale price control are intricate and very likely would frequently show themselves in strengthening private brand and unbranded items. Also, there is the fact that many advertised packaged grocery products are excellent "loss leader" items. This is a condition that to some extent leads to a demand for price control; likewise, it is a resisting influence insofar as the cutters prefer to employ these wellknown brands. Finally, there is the matter of inter-outlet competition. Groceries are sold in many types of outlets under diverse conditions. A

41 For a detailed review see the writer's discussion: Grether, Trends in the Wholesale Grocery Trade in San Francisco (1930) 8 HARv. Bus. REv. 443-50. 
grocery product that is part of the main line of a specialist may be merely a side lime to another type of dealer. This condition of inter-outlet competition is further aggravated by a wide range in equipment and services between firms in the field; consequently any attempt at standardization of prices and margins would lead both to definite resistance and to the introduction of compensatory influences in other directions.

In the fourth place, there is the private brand threat. Private branding was mentioned above but is sufficiently important for separate treatment. The brands of chain stores, wholesalers, cooperative and voluntary chains and some of the larger dealers are already thoroughly intrenched. The constant pressure and threat of these brands makes manufacturers who are selling on an identified, branded basis exceedingly wary about any schemes that might give any advantage to these actual or potential arch competitors. The situation unfortunately, is not clear cut. It is claimed by many that at present prices are slashed on well-known national brands in order to lure customers into the stores to sell them privately branded merchandise. Also, it is held that dealers put pressure behind private brands because of the absence of profit in the handling of the well-known brands that are used as leaders. There is much evidence to support both of the above propositions. Conversely, it seems equally true, that with the prices of national brands stabilized, the price cutters and the cham stores, super-markets and large scale distributors in general would be forced to stress their private brands in order to obtain a differential position in the market. It seems to the writer that neither of these general propositions nor their application with respect to any given item or line is subject to precise quantitative formulation or prediction for the outcome should be highly variable between firms. Two considerations stand out: (1) stabilized advertised brands provide ideal standards of comparison for those who wish to push private brands; (2) many advertised brands probably could maintain and improve their position by increasing advertising and selling expenditure and by the aid of the goodwill of many independent merchants. Although it is exceedingly difficult to be certam of the proper conclusions, the writer inclines to the belief that many private brands would expand their sales under conditions of retail price control because of the dominance of the economy-price element in consumer buying of groceries.

Finally, there is the strength of the interests in opposition. Arrayed against resale price maintenance on the whole are the limited and nonservice outlets, the price cutters, the cham stores, the super-markets and the grocery departments attached to department stores. The volume of sales of these outlets is so large that manufacturers will be exceedingly wary about employing a practice which might antagonize them, causing 
a loss of their business or which particularly, might lead thein to push their own brands or non-controlled lines. A voluntary scheme of resale price maintenance would of necessity gain its power only from a sufficiently well organized, coercive demand from the balance of the retail trade.

The weight of the evidence and of the above analysis points to the conclusion that resale price maintenance as a permissive scheme cannot have general or even wide use in the sale of food products. Here and there, individual suppliers or small groups of firms who are well entrenched and have simple, direct relations with their dealers, and find cooperation with their competitors easy, and are without a serious private brand threat, may operate successfully in this vertical manner. However, voluntary resale price control does not appear feasible at present even with the powers granted in the 1933 amendment. This conclusion with respect to California is re-enforced by the fact that in Great Britain with broad legal rights and a history of half a century, resale price maintenance is still relatively weak and meffectual in the grocery trade. ${ }^{42}$

EXPERIENCE IN THE GROCERY TRADE UNDER THE UNFAIR PRACTICES ACT THE PERIOD PRIOR TO NINETEEN THIRTY-FTVE

The anti-discrimination act of 1931 and the sales below cost act of 1933 which provided the core of the Unfair Practices Act of $1935^{43}$ were invoked only a sinall number of times in the period prior to 1935 . In the city of Fresno in the spring of 1932, a chain store was convicted of varying prices between stores within the city for the purpose of destroying competition. According to the evidence offered, one unit of the chain was sellimg Ivory Snow two packages for five cents; at the same time other units were selling it at thirteen cents a package. It was alleged that the purpose of this variation in prices was to beat the advertising of an independent competitor who had offered to sell the same product at two packages for twenty-five cents. ${ }^{44}$ The ruling of the lower court was affirmed on appeal to the superior court.

The 1933 sales below cost act was used more largely as a potential threat and in an educational manner than in prosecution in the courts. There was considerable publicising of the penalties of the act together

42 Cf. GRETHER, op. cit. supra note 10, section V. Since the writer's investigation in 1933, apparently there has been an increase in activity in the grocery trade in Great Britain. In a review of the writer's study, in the Producer, February, 1936 (published by the Cooperative Wholesale Society of Great Britain), it is stated: "there has been a change in the title and constitution of the grocery trade price maintenance association and an increase in its activity."

43 Supra note 3.

44 California Retail Grocers' Adwocate, December 25, 1931, p. 8; Ibid., Mar. 11, 1932, pp. 1I, 13, 17; Ibid., July 8, 1932, p. 5. 
with conferences with members of the trade who were deemed to be violators. However, a small number of attempts at prosecution appeared. The first case in which the defendant was held guilty was that of a dealer in southern California who had sold butter at five cents a pound in combination with other articles at a time when the average wholesale price of butter was twenty-one cents a pound. This verdict was entered by a jury of nine women and three men in a justice of the peace court. ${ }^{45}$

In the prosecutions and in the persuasive work among the members of the trade only sales below invoice cost were considered violations of the law. In a number of instances, attempts at prosecution failed because the "cutters" were able to produce their invoices. In another instance, prosecution failed because of lack of agreement that there was "intent to destroy competition" as well as for lack of evidence of sale below $\operatorname{cost}^{46}$ In another instance, an imjunction was granted against a firm in San Francisco for violation of the Code of Fair Competition of the Retail Food and Grocery Trade and for violation of the sales below cost statute. ${ }^{ \pm \pi}$

ORGANIZATION OF THE TRADE FOLLOWING THE NINETEEN THIRTY-FIVE ACT

Upon the passage of the Unfair Practices Act a major movement developed to organize the food trade under its ægis. The experience of the N.R.A. code was still fresh in the minds of the inembers of the trade and hence the code pattern was followed. Early in the summer of 1935 the dealers in southern California organized The Southern California Food and Grocery Bureau to police the trade. Shortly thereafter a similar movement arose in northern California. In the northern part of the state two major orgamizations came into existence as well as a number of smaller arrangements in connection with local grocers' associations. The first of the major organizations was the Food Trades Institute, sponsored by the California Grocers' and Merchants' Association, with headquarters in San Francisco. ${ }^{48}$ The second was the Food Industry Bureau in Alameda and Contra Costa counties with headquarters in Oakland. This latter body was announced as "succeeding the food and grocery code authority" and was set up late in the summer of $1935 . .^{49}$ Gradually

\footnotetext{
45 California Retail Grocers' Advocate, Sept. 29, 1933, p. 7.

46 Commercial Bulletin, Feb. 1, 1935, p. 1, in a news item headed "Dismiss Loss Leader Charge Against Smith."

47 People v. Wunner, in the Superior Court of San Francisco, No. 249933, E. P. Morgan, Judge. California Retail Grocers' Advocate, June 15, 1934, pp. 7, 9.

48 Reported in California Retail Grocers' Advocate, Aug. 30, 1935, pp. 17, 21. See ibid., Aug. 2, 1935, pp. 17, 18 for the original plan for the bureau.

49 California Retail Grocers' Advocate, July 26, 1935, p. 22 for preliminary organization announcement.
} 
activity of a similar natire appeared in connection with local grocers' associations $^{50}$ throughout the state.

The general procedure of the various organizations seems to have followed the original program that was laid out in the first proposed plan; viz., "first, to make interpretation of the various provisions of the Act as it pertains to the food and grocery industry; second, see that these interpretations are passed on to the industry; third, receive complaints of violation; fourth, endeavor by persuasion to amicably settle complaints; fifth, where this is impossible, to prepare and file action through the District Attorney's office." "51 Bureaus have been supported by assessments and voluntary contributions. It was planned at first to proceed with assessments as under the code, but it has been difficult to obtain and maintain support. ${ }^{52}$

Although the stated purposes of the various regulatory bodies involve the regulation of trade practices in general, the core of their work has dealt with the curbing of sales below cost. Throughout the state there appears to have been the uniform policy of using the invoice or replacement cost of merchandise plus six per cent as the minimum lawful base price. It is without doubt not accidental that six per cent was employed as the mark-up figure, for this is the figure also used under the code as the loss himitation provision which established the floor of the market. Under the code, however, the six per cent figure was assumed to bear some relation to labor costs; under the Unfair Practices Act, full overhead costs are supposed to be included. Very few, if any, dealers can cover expenses with a six per cent mark-up. At the best, this would be the margin essential to cover expenses only in the case of efficient, limited service establishments in the sale of non-perishable staple items. Obviously, the various classes of food products have widely different expense rates; effective operation under the Act should eventually reflect these differences in a number of base rates, rather than the flat six per cent figure. 53

For the most part the regulatory activities of the various groups throughout the state have expressed themselves in persuasive efforts

50 The Santa Clara association had its first court case September 4, 1935. Califormia Retail Grocers' Advocate, Sept. 6, 1935, p. 14. The Sacramento Association became active early in the fall. See ibid., Nov. 22, 1935, p. 29. Sonoma, San Luis Obispo, Monterey and Santa Cruz dealers began to take action in the spring of 1936. (See Advocate, Mar. 20, May 1, and May 15, 1936.)

51 California Retail Grocers' Advocate, Aug. 2, 1935.

52 In California Retail Grocers' Advocate, Mar. 13, 1936, p. 13 it is stated: "so far, if we may judge by the support given, it would appear that the industry does not want the protection which this law affords."

53 The problem of the legal and economical mark-up under the Act will be discussed infra. 
through conferences and dissemination of printed materials. However, there have been a considerable number of cases presented to the California courts. The California Retail Grocers' Advocate in January 1936 reported that at the time there were fourteen prosecutions under way in California. To date, there has been no supreme court case; hence, the legal issue is still unsettled. Throughout the state, the bulk of the decisions have been favorable as in the case of the Fair Trade Act. The supreme court decision in the Max Factor ${ }^{54}$ case is taken by the members of the trade as indicative of what will happen when the Unfair Practices Act is tested. The leading adverse decision thus far was in the case of Balzer v. Coler, in the superior court of Los Angeles County, Superior Judge Clarence $\mathrm{L}$. Kincaid..$^{55}$ The leading favorable case was not directly in the grocery industry, but in the tobacco field and was almost simultaneous with the one above. It was the case of Wholesale Tobacco Dealers Bureau of Southern California v. Nat. Candy $\mathcal{E}$. Tobacco Co., in the superior court of Los Angeles County, Superior Judge Minor Moore. ${ }^{56}$

It is still too early for thorough-going review of action in the courts, or for economic evaluation. As far as the food trades are concerned at present it is clear that there is a major movement to stabilize prices under the Unfair Practices Act; further, that the movement to date has achieved much success. So much so, that it is spreading to other trades in California. 57

\section{THE DRUG TRADE}

Prior to 1933 there was some resale price maintenance in the drug trade on the part of individual manufacturers. However, neither the favorable supreme court decisions following the 1909 amendment to the Cartwright Act nor the 1931 Fair Trade Act led to a significant movement in this direction. ${ }^{5 s}$ The reasons for the lack of use of the 1931

\footnotetext{
54 Supra note 18.

55 Opinion No. 395,809 . Text of the opinion was reported in the Los Angeles Daily Journal, Feb. 24, 1936.

56 Opinion No. 393434. Text of the opinion was reported in the Los Angeles Daily Journal, Feb. 25, 1936; also in California Retail Grocers' Advocate, Mar. 6, 1936.

57 Late in the spring of 1936, an interesting and significant attempt at price stabilization appeared in another branch of the food industry, under the combined rights of the Calmorinta Marketing Agremanent Acr of 1935, Cal. Stats. 1935, p. 1856, and the UnFaIr Practices Acr. This effort was on the part of manufacturers of macaroni. Under the agreement, industry boards have been set up for northern and southern California; a list of unfair practices has been promulgated; an open price system bas been established, and sales below cost have been included anong the unfair practices. The arrangement is strictly a marketing agreement between the industry and the Director of Agriculture; its prime significance for this paper lies in the fact that it also makes use of the UNFaIR Practices Acr.

58 Cf. Warnack, The California Fair Trade Act (1935) 8, 9.
} 
law apparently were: (1) the inherent quality of the statute as'a permissive contractual act; (2) the lack of control over dealers who refused to sign; (3) the ease of access to supplies outside the state; (4) the full depression influences were not felt as yet; (5) manufacturers on the whole were more interested in volume than in stabilizing the retail market; (6) the absence of a concerted effort in the retail trade to exert pressure upon manufacturers to operate under the act. It was the 1933 amendment and the N.R.A. code experience that both reflected and provoked the renewed and enlarged interest in the problem.

\section{TRADE CONDITIONS IN 1933}

The full meaning of the developments since 1933 cannot be grasped without reference to the price conditions in the drug trade in the bottom of the depression. Cut rate selling had long been prevalent in the trade; the depression gave it general popularity, particularly in the metropolitan centers, and often in smaller outlying points. The limited service, low price types of establishments thrived as the price conscious consumers thronged to then in increasingly larger numbers. Especially because many, perhaps most, of the independent service stores preferred to hold prices rather than enter into drastic price wars. Advertising pages were filled with bargain offers in which comparative price appeals were dominant. In addition, it appears that many offered bait merely for the purpose of luring customers into stores. There can be little doubt that healthy price competition became heavily infected with unfair practices. When the code went into effect, these practices found a haven in the files of the code authorities.

The writer has made a number of price studies to indicate price conditions in the retail drug markets of the state during the first six months of 1933 insofar as they were reflected in the advertising of retail drug firms in newspapers throughout the state. In all of these price studies only those items were employed which in 1934 went under Fair Trade contracts. Hence, it is possible to contrast the advertised retail prices at the bottom of the trough with the minimum and fixed contractual prices in 1934. Also, it is possible to compare the bargain claims of the advertisers with their actual prices and with the contractual prices.60 The studies provide a sample of prices not only in the metropolitan areas of Los Angeles and San Francisco, but im smaller cities and rural com-

59 These price studies were limited by the availability of 1933 newspapers files in the Bancroft Library of the University of California. Price data have been collected and analyzed for the following California cities and towns: Los Angeles, San Francisco, Stockton, Modesto, Riverside, Santa Barbara, Turlock, Visahia, Exeter, Corona, Dos Palos, Martinez. In some of the smaller towns only a small number of quotations were available due to the paucity of advertising by druggists. 
munities. Table I depicts in detail the results of the San Francisco computation. Table II does the same for Stockton. Lack of space makes it impossible to reproduce the complete tabular summaries for all the commumities in this article; only the general averages will be used here. ${ }^{60}$

TABLE I

COMPARISON OF ADVERTISED PRICES ON DRUG PRODUCTS IN SAN FRANCISCO, CALIFORNIA, DURING THE PERIOD JANUARY 1 TO JUNE 30, 1933, WITH 1934 CONTRACTUAL PRICES FOR IDENTICAL ITEMS

(Prices taken from advertisements in the San Francisco Examiner) Figures in percentages of contractual prices

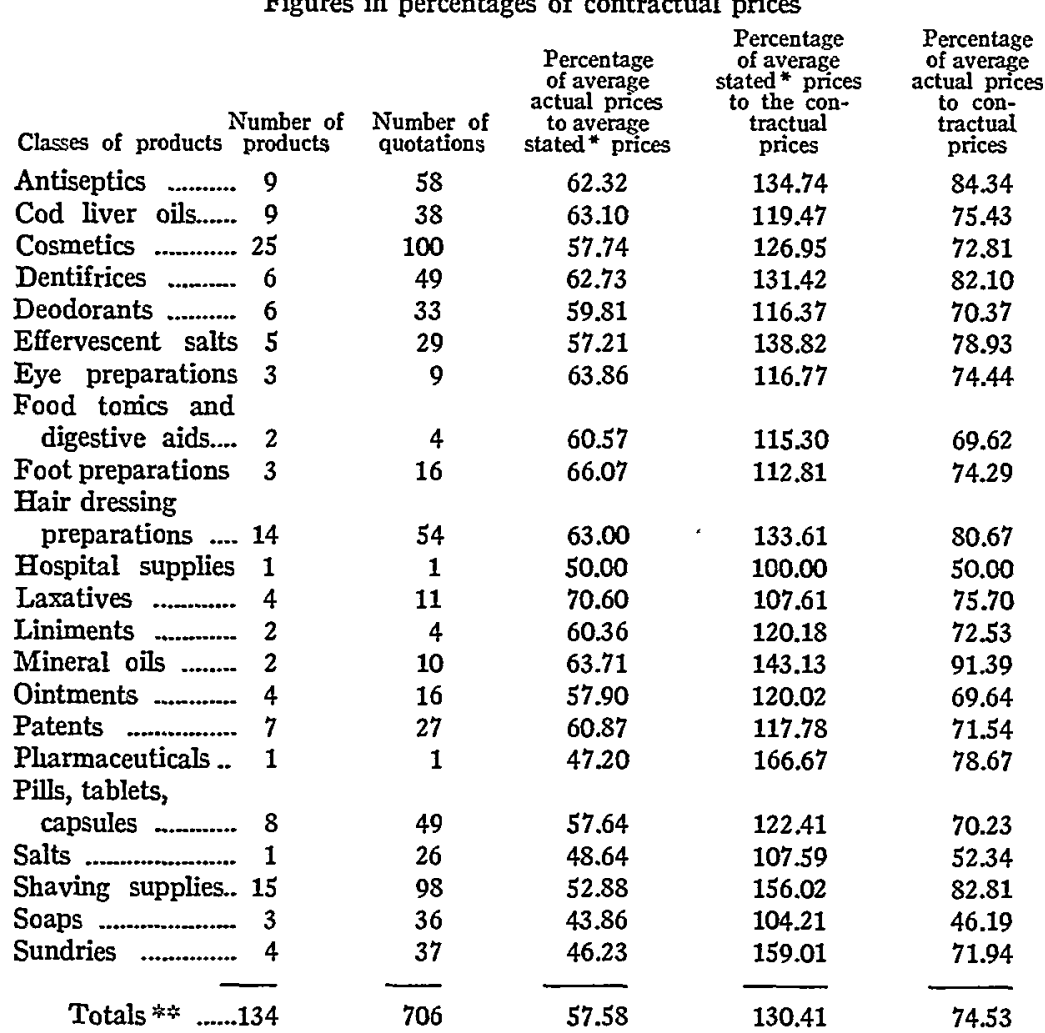

* The stated price is the price from which the advertiser alleged he was cutting; the actual

* price is the price at which he was selling.

${ }^{60}$ The averages in the tables and in all studies are simple weighted averages. The class and total averages were weighted by the number of price quotations for each commodity. The figures for San Francisco and Stockton given here differ slightly from those in MERREIx, GRETHER \& KITTELIE, supra note 4, because these earlier coinputations were unweighted. 
TABLE II

COMPARISON OF ADVERTISED PRICES ON DRUG PRODUCTS IN STOCKTON, CALIFORNIA, DURING THE PERIOD JANUARY 1 TO JUNE 30, 1933, WITH 1934 CONTRACTUAL PRICES FOR IDENTICAL ITEMS

(Prices taken from advertisements in the Stockton Record) Figures im percentages of contractual prices

\begin{tabular}{|c|c|c|c|c|c|}
\hline Classes of products & $\begin{array}{l}\text { Number of } \\
\text { products }\end{array}$ & $\begin{array}{l}\text { Number of } \\
\text { quotations }\end{array}$ & $\begin{array}{l}\text { Percentage } \\
\text { of average } \\
\text { actual prices } \\
\text { to average } \\
\text { stated " prices }\end{array}$ & $\begin{array}{l}\text { Percentage } \\
\text { of average } \\
\text { stated prices } \\
\text { to the con- } \\
\text { tractual } \\
\text { prices }\end{array}$ & $\begin{array}{c}\text { Percentage } \\
\text { of average } \\
\text { actual prices } \\
\text { to con- } \\
\text { tractual } \\
\text { prices }\end{array}$ \\
\hline Antiseptics & 8 & 21 & 69.11 & 132.52 & 91.20 \\
\hline Cod liver oils ...... & - 3 & 12 & 63.44 & 116.04 & 74.08 \\
\hline Cosmetics ............ & .15 & 29 & 64.85 & 129.84 & 82.89 \\
\hline Dentifrices ........... & - 9 & 26 & 64.30 & 127.56 & 83.40 \\
\hline Deodorants ........... & 7 & 27 & 64.13 & 120.59 & 76.81 \\
\hline Effervescent salts & 6 & 12 & 57.71 & 118.18 & 70.23 \\
\hline Eye preparations & 2 & 3 & 66.17 & 118.56 & 78.39 \\
\hline Foot preparations & $\mathbf{1}$ & 6 & 72.57 & 112.90 & 77.42 \\
\hline preparations .... & . 6 & 16 & 65.99 & 128.91 & 84.61 \\
\hline Hospital supplies & 2 & 3 & 74.93 & 103.98 & 77.59 \\
\hline Laxatives & 3 & 9 & 58.65 & 101.03 & 59.21 \\
\hline Mineral oils ......... & 1 & 1 & 84.00 & 127.11 & 106.79 \\
\hline 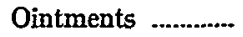 & - 7 & 11 & 60.09 & 117.59 & 71.02 \\
\hline Patents & 3 & 5 & 65.95 & 113.45 & 74.60 \\
\hline $\begin{array}{l}\text { Pharmaceuticals .. } \\
\text { Piils, tablets, }\end{array}$ & 2 & 4 & 78.34 & 114.20 & 88.55 \\
\hline capsules ................ & 11 & 23 & 63.11 & 115.07 & 72.49 \\
\hline Salts & 4 & 15 & 58.73 & 119.66 & 70.52 \\
\hline Shaving supplies.. & 9 & 19 & 57.69 & 138.70 & 79.22 \\
\hline Soaps & - 2 & 2 & 58.00 & 166.67 & 96.67 \\
\hline 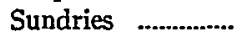 & - 9 & 27 & 62.88 & 125.86 & 74.84 \\
\hline Totals ** ......1 & .110 & 271 & 63.70 & 123.63 & 78.50 \\
\hline
\end{tabular}

* The stated price is the price from which the advertiser alleged he was cutting; the actual price is the price at which he was selling.

In San Francisco (see Table I) advertised drug prices averaged 74.53 per cent of 1934 contractual prices. Also, advertisers in their statements of comparative prices were cutting from prices which were stated (the stated prices of the tables) as 130.41 in relation to contractual prices of 1934, used as the base of 100 . The actual prices averaged 57.58 per cent of the alleged comparative prices of the advertisers. Thus 1934 contractual prices stood near the mid-point between the 1933 stated and actual prices. Most important for this study is the fact that the acual advertised prices in 1933 were 25.43 per cent lower than the 1934 contractual minima; or, shifting the base, 1934 contractual prices were approximately one-third above the average of advertised prices for the first six months of 1933. A glance at Table I will disclose that there was a considerable variation between classes of products. 
The Los Angeles price study showed results almost identical with those in San Francisco in spite of common behef that prices were much lower in Los Angeles. In Los Angeles the actual 1933 prices averaged 75.3 per cent of the contractual prices, or .8 per cent higher than San Francisco. Interestingly enough, the level of stated prices also was about the same amount above San Francisco, 131.2 per cent in relation to 130.41 in San Francisco. Advertising claims were equally exaggerated in both San Francisco and Los Angeles. The ratio between actual and alleged (stated) prices necessarily, therefore, was also practically identical for Los Angeles; 57.87 per cent in comparison with 57.58 per cent for San Francisco.

As one moves from the two dominant metropolitan areas of the state, the degree of price cutting is less, although there is one notable exception, the town of Modesto. A priori, one would assume price cutting to be more severe in the inetropolitan areas, and that this influence would be communicated in a diminishing manner into outlying areas. The evidence seeins to indicate that this assumption is true with respect to advertised drug prices. Exceptions are to be expected (as in the case of Modesto) because of local competitive variables. Occasionally for a period a dealer will cut heavily in a small town and create large competitive price reductions. Most frequently, it appears that the level of retail prices is considerably higher in the drug business in small, especially rural, centers. Space does not perinit a discussion of each city or town separately. ${ }^{\text {t1 }}$ The listing below portrays the general averages for the cominunities arranged according to size.

\begin{tabular}{|c|c|c|c|c|c|c|}
\hline City or Town & $\begin{array}{l}1930 \\
\text { Popu- } \\
\text { lation }\end{array}$ & $\begin{array}{l}\text { No. of } \\
\text { pro- } \\
\text { ducts }\end{array}$ & $\begin{array}{l}\text { No. of } \\
\text { quota- } \\
\text { tions }\end{array}$ & $\begin{array}{l}\text { Percentage } \\
\text { of average } \\
\text { actual } \\
\text { prices to } \\
\text { average } \\
\text { stated * } \\
\text { prices }\end{array}$ & $\begin{array}{l}\text { Percentage } \\
\text { of average } \\
\text { stated * } \\
\text { prices to } \\
\text { the con- } \\
\text { tractural } \\
\text { prices }\end{array}$ & $\begin{array}{c}\text { Percentage } \\
\text { of average } \\
\text { actual } \\
\text { prices to } \\
\text { contractual } \\
\text { prices }\end{array}$ \\
\hline Los Angeles .... & 238,048 & 210 & 966 & 57.87 & 131.22 & 75.31 \\
\hline San Francisco & 634,394 & 134 & 706 & 57.58 & 130.41 & 74.53 \\
\hline Stockton & 47,963 & 110 & 271 & 63.70 & 123.63 & 78.50 \\
\hline Santa Barbara & 33,613 & 76 & 283 & 58.20 & 130.84 & 75.40 \\
\hline Riverside ........... & 29,696 & 53 & 98 & 61.44 & 122.05 & 74.72 \\
\hline Modesto & 13,842 & 68 & 264 & 55.37 & 125.84 & 69.46 \\
\hline Visalia & 7,263 & 64 & 270 & 77.67 & 122.70 & 96.41 \\
\hline 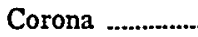 & 7,018 & 20 & 25 & 68.23 & 125.17 & 85.53 \\
\hline Martinez ........... & 6,569 & 23 & 34 & 73.37 & 119.85 & 84.85 \\
\hline Turlock ............... & 4,276 & 28 & 41 & 63.57 & 131.06 & 87.44 \\
\hline 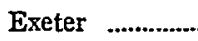 & 2,685 & 22 & 31 & 84.00 & 123.85 & 103.65 \\
\hline Dos Palos Un & er 1,000 & 27 & 43 & 73.57 & 118.53 & 87.10 \\
\hline
\end{tabular}

* The stated price is the price from which the advertiser alleged he was cutting; the actual price is the price at which he was selling.

In the above studies the averages were coinputed from a sampling of all retail drug advertising. No attempt was unade to segregate firms known

61 Supra note 4. 
to be price cutters. Also, there was no reference to the relationship between the advertised retail prices and wholesale prices. Two specific examples of the advertising of individual firms assist in illuminating the problem. In November 1933, a Los Angeles retail drug firn, famous as a price cutting institution, in three advertisements in the Los Angeles Evening Herald, advertised seventeen articles below the regular, published wholesale list price. These seventeen products varied from 52.9 per cent of the wholesale list to 88.6 per cent; the arithmetic average was 74.2 per cent. That is, this particular firm was offering to sell these items from 47.1 per cent to 11.4 per cent below the regular wholesale price; on the average it had cut 25.8 per cent below the wholesale list. Table III summarizes an isolated similar example in San Francisco. In this case it is also possible to inake comparison with the then recommended prices of the Northern California Retail Druggists Association. It will be noticed that of the 106 items, only eight were offered at prices above the published wholesale list; only six at wholesale and ninety-two below wholesale. The arithmetic average of the prices of the 106 items was 11.9 per cent below the regular wholesale list. The advertised prices averaged 36.9 per cent below the then recommended prices of the Retail Druggists' Association. ${ }^{62}$

TABLE III

COMPARISON OF THE ADVERTISED PRICES OF A SAN FRANCISCO

PRICE CUTTER IN 1933 WITH THE CURRENT PUBLISHED WHOLE-

SALE PRICES AND WITH THE PUBLISHED RECOMMENDED

RETAIL PRICES OF THE NORTHERN CAIIFORNIA RETAIL DRUGGISTS ASSOCIATION

\begin{tabular}{|c|c|c|c|c|c|c|}
\hline & \multicolumn{3}{|c|}{ Price level } & \multirow{2}{*}{$\begin{array}{l}\text { Average } \\
\text { percentage } \\
\text { of cut prices } \\
\text { above or } \\
\text { below } \\
\text { wholesale }\end{array}$} & \multirow{2}{*}{$\begin{array}{l}\text { Average } \\
\text { percentage } \\
\text { reduction } \\
\text { of adver- } \\
\text { tised cut } \\
\text { prices } \\
\text { below } \\
\text { druggists' } \\
\text { association } \\
\text { prices }\end{array}$} & \multirow{2}{*}{$\begin{array}{c}\text { Average } \\
\text { percentage } \\
\text { margin on } \\
\text { druggists } \\
\text { recommend- } \\
\text { ed prices }\end{array}$} \\
\hline $\begin{array}{l}\text { Date and } \\
\text { place of ad- } \\
\text { vertisement }\end{array}$ & $\begin{array}{l}\text { Above } \\
\text { whole- } \\
\text { sale }\end{array}$ & $\begin{array}{c}\text { At } \\
\text { whole- } \\
\text { sale }\end{array}$ & $\begin{array}{c}\text { Below } \\
\text { whole } \\
\text { sale }\end{array}$ & & & \\
\hline \multicolumn{7}{|l|}{ Aug. 10, 1933} \\
\hline Bulletin ......... 15 & 5 & 1 & 9 & -9.6 & 35.5 & 31.4 \\
\hline \multicolumn{7}{|l|}{ Sept. 7, 1933} \\
\hline Bulletin ............ 26 & $\mathbf{0}$ & 2 & 24 & -13.3 & 37.4 & 29.7 \\
\hline \multicolumn{7}{|l|}{ Sept. 10, 1933} \\
\hline S. F. Examiner 26 & 0 & 1 & 25 & -13.7 & 37.5 & 29.5 \\
\hline \multicolumn{7}{|l|}{ Oct. 15,1933} \\
\hline S.F. Examiner 39 & 3 & 2 & 34 & -10.6 & 36.7 & 30.3 \\
\hline Total $* \ldots \ldots$........ & 8 & 6 & 92 & -11.9 & 36.9 & 30.1 \\
\hline * Total percentages are a & egate ave & ges. & & & & \\
\hline
\end{tabular}


Although it would be a serious error to interpret the long-run demands for resale price maintenance in terms of depression influences, it is sound to assume that the vitality of the movement in Califorma in 1933 and thereafter, as well as the general insistence upon price stabilization devices is intimately linked with the retail price situation described above. As a check upon the above results a computation was made of a sample of drug prices advertised in the San Francisco Examiner during the first six months of 1935 in comparison with the contractual-prices of October 1935. The 877 quotations averaged 92.5 per cent of the October fair trade minimum prices. ${ }^{63}$ The significant point is that advertised prices in 1935 computed on a similar basis to 1933 stood at 92.5 per cent in contrast to 74.5 , an increase of 18 poimts or 24.3 per cent. That is, as far as advertised prices were concerned the price level on fair trade items was almost one-fourth lower in San Francisco in 1933. It should be noted that there are qualitative factors in the problem which cannot be computed statistically. Particularly important is the extent to which prices and margins in 1933 were held constant or widened or narrowed on merchandise which was not advertised. ${ }^{.4}$ Most serious of all is the problem of prices in relation to quality on non-standard merchandise. In spite of these difficulties there is little doubt that the conditions of the 1933 market produced a decided willingness among retailers to cooperate in an effort to stabilize their markets. It should be noted that this is a plain statement of the forces operating; not an evaluation of the economic soundness of this attitude. It is as essential to be aware of the nature of the forces working in society as it is to have sound abstract criteria of evaluation. For our society, the criteria of economic judgment are apt to be less abstract and more sound imsofar as they are related to the intimate workings of the market. For the present purpose it may be safely stated that the 1933 results in California should be evaluated in relation to the disrupted retail markets; conversely, it is not at all unlikely that the group efforts which produced the legislative and trade results during and following 1933 will be unable to maintain themselves effectively during better market conditions.

THE PERIOD OF THE N.R.A. CODE

The demand for resale price maintenance grew in intensity during the period of the code. This outcome appears anomalous since it might be expected that the code regulations would have shifted the focus of

03 The fact that this figure is lower than the contractual minimum is accounted for by the following: (1) some items during the first six months were as yet uncontrolled; (2) enforcement has not been perfect; even in advertising there have consistently been some violations; (3) there is apt to be a lag between the establishing of minimum price by the manufacturer and retail price practices. 677-678.

64 The results of studies of prices in independent retail stores is given infra. pp. 
interest in the trade. So far as the retail trade is concerned it appears that the code accentuated, rather than allayed, the demands for resale price maintenance. In the first place, retail druggists were for the most part dissatisfied with the price provisions of the retail code. They had fought for provisions which would have included comfortable margins in minimum selling prices. ${ }^{65}$ To them the loss limitation provision which they received, which fixed the minimum price at delivered wholesale price in dozen lots, seemed a weak compromise. In the second place, in California, especially in the Los Angeles area, there was tremendous dissatisfaction among the majority of retail druggists with the enforcement of code provisions. In the third place, the relative brevity of the code period makes it impossible to know what the ultimate outcome might have been, particularly if it had continued long into a condition of "normal" markets. Possibly the trade eventually might have become more contented under code administration. In the fourth place, the code provided a pattern and the occasion for bringing the members of the trade more closely together, thus facilitating the organization which showed itself in the vigorous pursuit of resale price maintenance, and to some extent, stabilization under the Unfair Practices Act.

THE EXPERTENCE AND ATTITUDES OF RETAIL DRUGGISTS

In the summer of 1934, one hundred retail druggists were interviewed in the San Francisco Bay region, fifty in San Francisco, and fifty in the East Bay area. In this survey, there was no attempt at selectivity; i.e., the interviewer talked to dealers in each district as the opportunity was presented. As it happened, practically all the dealers who gave their opinions were independent pharmacists; hence, the survey largely expresses the stated opinions and attitudes of independent druggists in the San Francisco Bay region in the summer of $1934 .^{66}$

There is no doubt concerning the opinions and attitudes of these dealers. They unanimously approved resale price maintenance. They were equally unanimous in their support of the California Fair Trade Act. It is exceedingly significant by way of contrast to the grocery field and in relation to the quality of the organization of the trade, that all of these dealers were informed of the law. Ninety-two per cent stated that they were actively involved in supporting resale price control. Ninetyfour per cent stated that they pushed the goods of manufacturers who controlled prices more than uncontrolled products. The methods most frequently employed for pushing controlled items were: window and

65 For details see MERREII, GRETHER \& KrTTELIE, op. cit. supra note 4, part II, chaps. $3,4$.

66 In the grocery section the results of a similar survey among grocery retailers were given; see supra pp. 650-51. 
counter displays, personal recommendations and suggestions, and advertising. Uncontrolled items, it was stated, suffered not only from the aggressive attention given those under control, but by removal from display (even concealment), and refusal to purchase. This group of dealers gave every indication of knowledge of the law and active partisanship in furthering its use by manufacturers and wholesalers. Also, the inajority of the dealers (84 per cent) appeared fairly well satisfied with the quality of enforcement of prices under contract. However, there was some dissatisfaction with enforcement and with the width of the margins allowed retailers. ${ }^{67}$

In December, 1934, and January, 1935, sixty-two retail druggists were interviewed in Los Angeles. In this survey, a particular attempt was made to obtain opinions from firms that were known as price cutters in the trade. In Los Angeles, as in San Francisco, all of the dealers recognized the problem, and were informed concerning the law. Among the 62 firms interviewed, only seven opposed resale price maintenance; all of these firms were in the class coinmonly dubbed "pime board stores" by the trade; four operated more than one store. If actions speak louder than words then six additional firms in this class should be considered in opposition, for they were at the time aggressively cutting prices even though they stated they preferred control. Without exception, the higher and middle class firms favored price maintenance. The same attitude that was expressed with respect to the general question of resale price inaintenance showed itself in the question concerning the California Fair Trade Act. Forty-one of the firms stated that they were giving specific support to price maintenance through associational endeavor as well as by giving aggressive attention to controlled items (as in San Francisco). This group also was concentrated outside the limited service, price cutting institutions. In contrast to San Francisco, however, there was general dissatisfaction with the quality of enforcement. The dealers who favored resale price maintenance were unanimous that only a small number of manufacturers and distributors at this time were enforcing their prices effectively; the dealers in the opposition considered enforcement to be largely non-existent. ${ }^{6 s}$

Beyond the summaries just given there remain still the attitudes of the large scale retail types. There has been a reversal of attitude on the part of the larger chain systems in the last four years. In the earlier period, the large chains were ardent and active opponents of resale price

\footnotetext{
${ }^{67}$ For detailed statement of the comments of nine selected dealers see MerRELr, GRETHER \& KITTELLE, op. cit. supra note 4, pp. 242-244.

6s For a detailed statement of the comments of twelve selected dealers see Merreli, Grether \& Kittecte, op. cit. supra note 4, pp. 245-247.
} 
control. During the depression they became proponents of price maintenance. Apparently, the reason for this shift in attitude is directly related to the success that smaller price cutting institutions have had during the depression. A number of local operators with only one or a small number of outlets found they could beat the older, established institutions with the methods which they themselves had used. The drug chains had used loss leader price tactics as one way of gaining their foothold. Smaller, so-called "pine board" operators, found the depression markets ideal for similar tactics. Middle and upper class department stores likewise have either been actively supporting the movement for price maintenance or have been apathetic. This local attitude also runs counter to the general national policy of department stores expressed through the National Retail Dry Goods Association which has been the most influential single body opposing resale price control in this country. Department stores with limited service and a lower class clientele actively oppose resale price control. ${ }^{69}$

\section{THE EXPERIENCE AND ATTITUDES OF MANUFACTURERS AND WHOLESALE DISTRIBUTORS}

This field is too complicated and large to allow the collection of a complete, adequate set of evidence. However, the problem was illuminated in a three-fold fashion: (1) through interviews of a general random sample of firms; (2) by statements obtained from particular firms whose experience had been particularly significant; (3) by reference to published statements and advertisements, especially in The Northern California Drug News. Only a brief summary of interviews and the general conclusions are included in this paper. ${ }^{70}$

In the fall of 1934, fifty small and medium sized manufacturers of

$69 \mathrm{~A}$ few of the comments made to the writer by the head of a medium-sized price-cutting department store illustrate this attitude. This firm sells for cash and offers scant merchandising services and has relatively poor and inexpensive physical equipment. The head of the firm stated that operating expenses had ranged from $12 \mathrm{I} / 2$ to 18 per cent in recent years. If correct, this figure is half or less than half that of full service institutions. The firm puts all possible pressure upon resource markets to buy as cheaply as possible. In addition, it has built a reputation as a source of sale for distress merchandise; consequently, it is offered job lots of merchandise by manufacturers, wholesalers and even other retailers below the regular prices. It is also a heavy buyer of bankrupt stocks. The firm feels that it has a distinctive market which the majority of dealers cannot serve. The volume of sales of this firm increased very greatly during the depression. The firm at the time of the interview had signed no fair trade contracts, but was able to obtain goods as long as it did not cut below contractual prices. In those cases where price cutting was no longer possible the firm was pushing private brands. The attitude of the head of the firm was summarized as follows: "The small retail druggists want me to do business as they do, but this is an entirely different type of institution."

70 For the detailed comments of nimeteen selected firms see MERREL, GrETHER \& KITTELIE, op. cit. supra note 4, pp. 249-53. 
products sold through drug stores were interviewed in the San Francisco Bay region. Of these fifty smaller operators, forty expressed themselves as favoring resale price maintenance; yet the general attitude was one of apathy. Thirty-five firms felt that they were injured by price cutting in the retail trade; the balance stated either that it made no difference or that it benefitted thein. All of the forty which favored price maintenance stated that they suggested resale prices; only half of them made any attempt at control. Froin the fragmentary results of this particular interviewer's field work, it appears that small suppliers are neither especially interested nor, practically speaking, sufficiently involved in the problem to take a positive position.

Much more positive was the reaction obtained from interviews with firms selected either because of their prominence or their definite experience with price control. In January and July, 1935, twenty-nine firms were interviewed in Los Angeles; three of the group were wholesalers, the balance being manufacturers or their sales representatives in California. Eighteen of the twenty-six manufacturers were in favor of resale price control; sixteen of the eighteen spoke also for the California Fair Trade Act. Fourteen of this same group of sixteen were at the time employing Fair Trade contracts; the other two were planning to use them in the near future. Properly enough, this same group stated that price cutting in the retail trade imjured them; five of the balance said it benefited them, and the others said it was a matter of indifference. Only four of the twenty-six manufacturers did not suggest resale prices. Sixteen of the group were making efforts at enforcement. Of the eighteen firms that had experience in attempting to enforce resale prices (two of these had dropped their attempts at the time of the investigation), nine stated that prices could be enforced effectively; five felt that enforcement could be only moderately successful; four were dubious about the whole matter. All of them contended that effective enforcement required cooperation with the other members of the trade. Only ten stated positively that dealers appreciated efforts to stabilize prices.

It was exceedingly difficult to summarize the heterogeneous experiences, attitudes and opinions of the various manufacturers and wholesale distributors. However, the following conclusions forced themselves out of the evidence:

1. The experience and attitudes of manufacturers and distributors were exceedingly diverse.

2. The general attitude was one favorable to resale price control, but there were several violent objectors.

3. There was a great amount of indifference and skepticism, especially on the part of smaller firms. 
4. There was considerable agreement as to the difficulties of enforcement, especially because of ease of access to out-of-state sources of supply.

5. There was considerable agreement that effective enforcement required broad cooperation in the trade.

6. There was a general feeling of instability because of the legal uncertainty.

7. A number of firms were issuing contracts merely as a friendly gesture, and without any serious intention of enforcement.

8. There was considerable difference of opinion concerning the amount and quality of cooperation received from dealers after price control went into effect.

9. Wholesalers in the main are ardent advocates of resale price control because it is assumed that it would aid the small independent dealers and reduce the proportion of direct selling.

THE RETAII BASIS OF PRICE MIAINTENANCE IN CALIFORNIA

In its earlier phases the demand for resale price maintenance in the United States emanated largely from manufacturers. In its recent phase, the back bone of the movement is found in the retail trades, especially among individual, small-scale dealers aided by the wholesalers serving these dealers. In fact, many manufacturers in the current phase have been only lukewarm, if not actively opposed to price maintenance. The developments in the drug trade in California illustrate this reversal of support in a clear-cut fashion, for the movement towards resale price control since 1933 derived its vitality and momentum from the demands and organized methods of the retail druggists of the state. The strategy of the organized retailers to bring manufacturers into line included the following procedures: (1) educational work, (2) pressure upon firms by individual dealers through contacts with salesmen and by correspondence, (3) gaining the formal cooperation of allied drug trade groups, (4) militant organized refusal of cooperation to manufacturers who made no attempts at control, (5) organized cooperation with manufacturers who sincerely attempted to stabilize the market. The general program was effective in both larger centers and smaller communities, expressing itself through the regular retail associations and the militant so-called "Captain Plan" which ranged beyond the confines of association membership.

After the passage of the 1933 amendment, a Fair Trade Committee was set up in the California Pharmaceutical Association to encourage inanufacturers to operate under the Act. ${ }^{71}$ This committee made per-

\footnotetext{
${ }^{71} C f$. WARNACK, op. cit. supra note 58, pp. 10-18.
} 
sonal contacts with manufacturers, educating thein concerning the significance of the amendment. In September 1933 the committee sent a form letter, a sample suggested contract, and a copy of the law to several hundred leading manufacturers who used drug stores as outlets. This letter was entirely educational in quality and tone, ${ }^{72}$ explaining the act and amendment, and indicating how manufacturers could qualify themselves to operate im California. The final paragraph extended an offer of cooperation as follows:

"To those manufacturers who show a willingness to assist in our state recovery program toward sanity and stabilization of prices and who will operate under our Fair Trade Act, we can offer a wholesome cooperation and promotion of their merchandise that will result in our mutual welfare."

Concurrently, druggists were making their individual poimts of view felt. When salesmen dropped in for business, the proprietor would ask the attitude of their firms toward the Fair Trade Act, and suggest that it would assist orders to issue contracts. Shortly, dealers in their individual contacts became more aggressive and began refusing orders; in some instances even refusing a hearing to the representatives of firms outside the pale. Likewise, dealers frequently wrote letters to manufacturers expressing their opinions in unmistakable metaphor.

Late in the fall of 1933 , the efforts of the retail druggists received the organizational support of a larger group called the California Fair Trade Federation. The Federation incorporated representatives of all the inajor groups in the drug industry, except certain cut-rate institutions, and also allied associations in other fields. ${ }^{73}$ The stated primary purpose of the Federation was "to obtain as quickly as possible a validation of the law by the Supreme Court."

In the next place, there was the aggressive, militant action of retail druggists through their official associations. The publications of the association echo a great deal of this spirit. ${ }^{74}$ The action of the retail druggists officially took two general forms: (1) threats of non-cooperation with manufacturers who made no efforts to stabilize prices; (2) specific offers of assistance to those who made simcere efforts to operate under the Fair Trade Act. In addition there was also a growing attitude that pharmacists had allowed too much manufacturing to leave their own establishments and that they should make more of their own preparations. ${ }^{75}$ Militant activity was not confined to the larger cities;

$72 \mathrm{~A}$ copy is reproduced in WaRNaCK, op. cit. supra note 58, pp. 12-14.

73 Cf. The Northern California Drug News, Dec. 20, 1933, pp. 4, 8, 9.

74 See Northern California Drug News, Feb. 10, 1934, p. 9 and ibid., March 1, 1934, p. 3, for typical examples.

75 See Northern California Drug News, December 15, 1935, for the lengthy paper written by John Culley. In this paper Mr. Culley urged pbarmacists to return to their former professional status. He contended that retail druggists "are tired of 
small town druggists were also up in arms-refusing patronage, returning inventories to manufacturers and in general, sharing in the movement.

The organizational core of the retailers' militant program was the now famous so-called "Captain Plan" which has since spread to other parts of the country. There has been much discussion of the origin of the plan. As far as California is concerned it seems definitely settled that its progenitor was an Oakland, California druggist. The essence of the "Captam Plan" was merely the detailed organization of each district so that there was an effective quick means of gaining cooperation among druggists, whether members or non-members of the Association. A small group of dealers was assigned to a captain whose duty it was to get thein, insofar as possible, to operate as a unit. Through meetings, called usually at night after store hours so all might attend, personal discussions and informal contacts, the druggists often developed a collective attitude, policy and procedure. Under the plan there was both the constructive attitude of cooperation with friendly manufacturers as well as the negative one of opposition to those who did not meet the demands of the dealers. There can be little doubt that the plan was an effective element in the whole movement for resale price control. It appars, however, that it was much more influential near its birthplace in northern Califorma than in the Los Angeles area. ${ }^{76}$

The amount of strength that was demonstrated by retail druggists through the organizational devices discussed in the preceding pages may best be illustrated by two very famous cases. First, early in August, 1934, a well known aspirin manufacturer was requested by a petition of signatures twenty feet in length to operate under the Act. When the petition did not seem to receive the reception that the dealers expected, the published stateinents in the Northern California Drug News became increasingly antagonistic in tone. It was made clear in these statements that the dealers had the power of substitution even in this case. The slogan was "No Fair Trade Act-No Orders." The most terse statement of attitude was the following:

acting as a manufacturer's distributor without pay and many times paying for the privileges." He stated that the dealer "is obliged to keep in stock a dozen or more varieties of brands of proprietary remedies having similar fanciful coined naine, all containing the same ingredients, claiming as having the same extravagant inedical virtues and all outrageously over-priced, all of which is detrimental to the interests of the pharmacist, the physician, and to the public." Mr. Culley strongly advised pharmacists to do inore of their own manufacturing and offered a long array of examples to illustrate the savings that were possible.

76 For greater detail see WARNACK, op. cit. supra note 58, pp. 17 and 18 , and issues of the Northern California Drug News throughout the period. In addition to these published materials the writer has in his files opinions of a number of dealers, especially in Los Angeles. 
This Aspirin is a sort of Napoleon in the patent medicine army, but then, even the great Frenchman met his Waterloo when the rest of Europe got together, decided that they had enough of him and coöperated against him. 77

The outcome of the controversy was that the company issued fair trade contracts early in 1935.

The second case was publicized nationally and had repercussions throughout the entire country. It is peculiarly well adapted to reflect the state of mind of retail druggists throughout the nation as well as in California. In the January 1, 1935 issue of the Northern California Drug Nezes there is an editorial lauding a well-known national dentifrice and antiseptic manufacturer for finally issuing fair trade contracts after months of request, including a formal petition, on the part of retailers. The company was praised particularly because it guaranteed minimum margins of 18.4 per cent, 26.5 per cent, and 34.2 per cent, depending upon the quantity purchased. However, on July 13, 1935, dealers in California received letters from this firm advising them that it was necessary to withdraw from operation under the Fair Trade Act since they were making shipments directly from Chicago and hence were involved in inter-state commerce. Immediately, a storm broke loose in California which swept into other states before it had spent itself. On July 17 , the northern Association passed a resolution condemning the company and urging and advising its members to "discontinue the sale of the products of any and all companies which cancel Fair Trade contracts." Similar action was taken in the southern Association. The response of the trade was amazing; an almost universal boycott was raised against the firm. For a period it was possible to obtain the products of the firm only from a few cut-rate outlets. An interesting aspect was that a number of large wholesale houses also cooperated by refusing to deliver the items of the company. It appears that the company had a startling decline in sales in California. Worse still, the antagonism spread into other states and affected sales and attitudes nationally. The outcome was that the company capitulated completely, again issuing contracts in California, and likewise, so it is stated, giving a check of $\$ 25,000$ to the National Association of Retail Druggists to be used in its fight for price maintenance legislation.

\section{ENFORCEMENT}

The first step in operation under the Fair Trade Act is the issuance of contracts. Approximately three hundred and fifty manufacturers and wholesale distributors, large and small, have issued contracts. There is

77 The Northern California Drug News, September 20, 1934, p. 3. See also the issues of August 20, 1935, p. 5; September 1, 1934, p. 8; September 10, 1934, p. 3; December 15, 1934, p. 6; April 15, 1935, p. 5. 
considerable variation in the provisions of the contracts. The specific provisions of the various types of contracts will not be reviewed here. ${ }^{78}$ The general procedure is to issue contracts throughout the trade attempting to get a general coverage and then using the 1933 bludgeon on those who do not sign. The burden of enforcement necessarily falls upon the manufacturer. Manufacturers, however, are assisted to some extent by the voluntary work of wholesalers and retailers and by the retail association, and, in the southern part of the state, by a separate enforcing bureau which was organized to operate under the Unfair Practices Act and which broadened its scope to include the Fair Trade Act after the state supreme court decision. This bureau attempts full enforcement under the Unfair Practices Act but is primarily an agency for notification and persuasion in cases arising under the Fair Trade Act. The prime problem, however, inust rest with the manufacturers or their agents. Their problem would be greatly simplified if it were possible to organize price maintenance associations covering all of the classes of members in a trade as in Great Britain. Without doubt it is this nuisance of policing the trade which has made many manufacturers lukewarm in the matter. To date there have been many violations of contractual prices because of inadequate enforcement procedure on the part of manufacturers, especially on the products of manufacturers without good direct contacts in the state. Until the time of the supreme court decision, the legal uncertainty influenced many to lax supervision.

Now that the state supreme court has cleared the way at least temporarily, enforceinent should be more effective. At its best, though, it can never be perfect because of (1) the innumerable and variable devices of hidden evasion, (2) the great amount of effort often required on the part of manufacturers to maintain the personal and written contacts essential for the educational and persuasive aspects of enforcement, and (3) the policing, sleuthing, coding, marking, and the like, essential to the withholding of supplies froun cutters. The ultimate test of a manufacturer's attitude shows itself in his willingness or unwillingness to assume the expense of court action and the nuisance and expense of cutting off supplies froin price cutters. The latter problem is seriously complicated by the availability of supplies in other states. The relative difficulties of enforcement vary widely between firms depending upon the number of dealers, the degree of selective selling, whether the manufacturer has personal, direct, frequent selling contacts, the relative dependence upon cut-rate institutions, the desirability of given items for loss-leader purposes, the age, reputation and degree of monopoly power

78 For details see WarnacK, op. cit. supra note 58, and MerremI, Gretraer \& KITTELIE, op. cit. supra note 4, pp. 262-67. 
exerted by the vendor, and many other miscellaneous and variable factors. In view of the fact that this is merely a state-wide scheme, its effectiveness is decidedly tempered by the amount of stability in the given supplier's national situation. It is not surprising, therefore, that the relative effectiveness of enforcement is highly variable between firms. The only mamer in which the problem might be simplified and the burden made more equal is through broad cooperation among the various elements in the trade. ${ }^{79}$ It would appear, however, that group effort would be considered unlawful and that enforcement must continue to remain with the suppliers who issue contracts, assisted by the informal efforts of other trade factors. Even on this basis, the difficulties of enforcement are not insuperable in the drug business. In this respect it differs vitally from the grocery and some other lines. Not only are there fewer druggists but the problem of inter-outlet competition is greatly simplified within the field of drug products per se since their sale is restricted by law to drug stores. The bulk of open, public price cutting can be removed from the drug trade if manufacturers seriously set out to do it. No system could entirely remove the innumerable devices of hidden price cutting which can be devised by violators. ${ }^{80}$

THE EFFECTS UPON PRICES AND DEALER MARGINS THE PRICE IEVEL

The majority of contracts stipulate minimum resale prices, not fixed prices, although the first provision of Section 1 of the Fair Trade Act states: "the buyer will not resell such commodity except at the price stipulated by the vendor." Perhaps this usage is related to the wording of the 1933 amendment which reads: "at less than the price stipulated in any contract." However, a small proportion of contracts do establish fixed prices.

From the standpoint of the trade, as well as of the public, the impact of resale price maintenance upon the prices paid by consumers and upon dealer margins represents an ultimate criterion of evaluation. The effects upon dealer margins is intimately limked with the general impact upon consumer prices because these margins constitute such a large proportion of the prices paid by the final buyers.

The price problem, imsofar as evidence is available to date, may be stated in the forn of the following questions:

1. What are effects of resale price maintenance upon prices in the various classes of institutions in the trade?

${ }^{79}$ For a description in detail of the organization of a number of British trades see GreTHer, op. cit. supra note 10, pp. 276-83. Britain.

80 See ibid., pp. 284-300, for a discussion of the enforcement difficulties in Great 
2. What are the effects of resale price maintenance upon prices in various areas within the state, particularly the metropolitan, suburban, and rural markets?

3. What are the effects upon prices in California compared with markets outside the state where the identical items are sold?

There can be no doubt that resale price inaintenance under the California Fair Trade Act has nade for higher prices on advertised products sold through cut-rate and chain store institutions. The evidence presented above in the discussion of price conditions in 1933 in comparison with 1934 and 1935 contractual prices is conclusive on this point. ${ }^{81}$

In the metropolitan centers retail prices on advertised items were immediately raised on the average about one-third over 1933 prices and one-fourth of 1934 contractual prices insofar as they went up to the contractual level. The 1935 San Francisco study indicated that they did not immediately move up to this level, but fell seven per cent short. The evidence available from outlying centers indicates that on the whole the price increase was not as great in outlying centers for prices had not been cut as greatly (with the exception of Modesto) in these smaller centers. The writer is confident that if complete data were available it would be found that there was no price increase; in fact often a decrease, in many rural centers off the competitive influence of main arterials and without a local active price cutter. It must be reiterated, however, that the above conclusions have to do only with advertised drug prices, not with drug prices in general. As such, they reflect the effects of fair trade contracts upon these items primarily in price-cutting institutions and usually chain stores and large metropolitan cut-rate types. The great mass of small dealers cannot afford to buy newspaper space individually except in sinall towns. Also, it should be noted that this evidence is not at all conclusive concerning the effects upon all prices for all products in the stores that advertised in 1933, for: (1) it may not at all reflect the prices on items not advertised in newspapers, especially upon non-standard and privately branded goods; (2) there is no way of knowing to what extent the advertised prices were "bait" offered merely to attract patrons to the store and not supported by sufficient stocks to meet the full consumer demand. Often the intent of the price cutter is to substitute another brand for the brand advertised at a cut rate. ${ }^{82}$ Obviously, it is impossible to obtain adequate data covering the secret amount and quality of substitution taking place behind the public

\footnotetext{
${ }^{81}$ See especially Tables I, II, and III.

82 It is in this connection that manufacturers have the strongest claim for relief against price cutters, for the manufacturer's good will is used as a magnet to attract patrons to the store in order to sell them competitive goods.
} 
advertising barrage. The proper conclusion with respect to the problem is that operation under the Fair Trade Act has produced a significant increase in prices on advertised items sold through cut-rate and chain institutions, but that the absence of price data concerning all prices sold in these stores as well as of a measure of substitutionary influences, makes the evidence inconclusive concerning the full effects.

All of the evidence thus far assembled by the writer points to the conclusion that there is a wide difference with respect to the effects in the great mass of independent stores in contrast with the cut-rate and chain institutions. In January, 1935, twenty independent retail druggists in the San Francisco Bay region were presented with a list of one hundred drug products selected from the fair trade list. These druggists were asked to state their present selling prices for these items and also their selling prices immediately before these items went under contract. Because quotations in a small number of instances were given for two sizes, the final list comprised 105 quotations. The aggregate average of the present (i.e., January, 1935) selling prices was 105 per cent of the contractual minimum prices. The aggregate average of the former prices to the contractual prices was 114.6 per cent. That is, the going prices in these stores were approximately five per cent above the contractual minimum, and the prices prior to the issuance of contracts were almost fifteen per cent above the contractual minimum, and most startling, the going prices had fallen about nine per cent following the introduction of contractual controls.

In order to check upon the above result, which was quite surprising to the writer, additional price collections were obtained by interview in various parts of California during the spring of 1936. In March, 1936, the same list of items that had been used in San Francisco was presented to twenty-five druggists in Los Angeles, nineteen of whom were independent dealers who were not considered cut-raters; one was a chain store. Due to differences in market demand, prices were collected for only eighty-five of the one hundred items on the San Francisco list. For the entire group of stores the level of prices before the issuance of contracts was 94.19 per cent of the contractual minimum and the level afterwards, 101.60 per cent. When the nineteen non-cut-rate dealers were segregated it was found that the pre-contractual level was 105.13 per cent and the post-contractual level 105.97 per cent. For the six cutrate institutions the pre-contractual level was 83.25 per cent and the post-contractual level 96.88 per cent.

Following the Los Angeles investigation, a list of fifty items was developed which was considered an adequate sample and which included items in general demand throughout the state. The results of prices 
collected from ten independent druggists in Oakland, Berkeley, and Piedmont showed a general pre-contractual average of 109.98 per cent and a post-contractual average of 106.33 per cent. Ten independent stores im San Francisco had a pre-contractual average of 102.96 per cent and a post-contractual average of 102.61 per cent. Eight reports from small towns in Contra Costa County (Martinez, Crockett, Pinole, Concord, Rodeo) averaged 109.99 per cent for the pre-contractual prices and 110.44 per cent for the post-contractual prices. Nine reports from independent dealers in San Joaquin valley towns (Madera, Merced, Fresno, Tulare, Bakersfield) showed a pre-contractual average of 108.52 and a post-contractual average of 106.16. Eight reports from towns in southern California (Pomona, Ontario and Riverside) had a pre-contractual average of 100.52 per cent and a post-contractual average of 102.60 per cent. The forty-five reports based upon fifty products gave a precontractual total average of 106.44 per cent and a post-contractual total average of 105.53 per cent. Thus all of these collections of price data from independent retail druggists point to the conclusion that the issuance of contracts had little influence upon the general level of prices in these stores; if anything, it made for slightly lower prices. It was noticed that the general level of post-contractual prices was still somewhat above the contractual minimum. If prices in these independent stores eventually are lowered to the contractual mimima then the issuance of contracts will have actually made for a lowering of the price level in these stores. It seems a reasonable conclusion that in those markets where there is active price cutting, the tendency will be for the market to be established at the contractual minimum. In San Francisco, for instance, a group of independent druggists conducted a cooperative advertising campaign quoting minimum prices on the advertised items in an effort to inform the public that prices were at the rock-bottom in independent stores. Apparently before the issuance of contracts the great mass of independent dealers were unwilling to engage im drastic price wars with cut-rate institutions but preferred rather to hold prices and lose whatever volume was necessary. However, with contractual minima establishing a floor to the market they are quite willing to cut to that point since it is a stable one. Clearly here is contrasted an extraordinary difference in pricing policy even within the same locality between limited service, rapid turnover, cut-rate establishments and full service enterprises offering both the variety of goods and services essential to their given neighborhoods. ${ }^{83}$

83 Roy S. Warnack, Executive Secretary of the California Pharmaceutical Association, has assembled similar evidence in an unpublished survey of the prices on thirty-two drug products in 114 independent drug stores throughout California. $\mathrm{Mr}$. Warnack's general average of all items for all stores is 6.7 per cent lower after the issuance of contracts by contrast with previous prices. 
TABLE IV

COMPARISON OF PRICES ON IDENTICAL DRUG PRODUCTS IN DEPARTMENT STORES IN PORTLAND, OREGON AND TACOMA, WASHINGTON, WTTH CALIFORNIA CONTRACTUAL PRICES

(Figures are in percentages of contractual prices)*

\begin{tabular}{|c|c|c|c|c|c|c|}
\hline \multirow{3}{*}{ Classes of products } & PORTLAND & \multicolumn{5}{|c|}{ TACOMA } \\
\hline & \multirow{2}{*}{$\begin{array}{c}\text { Average per- } \\
\text { centage of } \\
\text { contractual } \\
\text { prices }\end{array}$} & \multicolumn{2}{|c|}{ Range } & \multirow{2}{*}{$\begin{array}{l}\text { Average per- } \\
\text { centage of } \\
\text { contractual } \\
\text { prices }\end{array}$} & \multicolumn{2}{|c|}{ Range } \\
\hline & & High & Low & & High & Low \\
\hline Antiseptics ......... 11 & 99.8 & 109.5 & 87.9 & 110.2 & 121.6 & 100.0 \\
\hline Cod liver oils..... 9 & 92.0 & 112.3 & 79.6 & 94.2 & 101.5 & 88.8 \\
\hline Cosmetics ........... 46 & 110.3 & 120.7 & 82.7 & 109.8 & 141.0 & 100.0 \\
\hline Dentifrices ......... 9 & 98.7 & 111.1 & 83.1 & 109.1 & 129.6 & 91.4 \\
\hline Deodorants ....... 10 & 96.0 & 102.1 & 83.0 & 111.3 & 145.8 & 100.0 \\
\hline Eye preparations 4 & 100.2 & 125.0 & 70.0 & 107.1 & 102.0 & 112.2 \\
\hline \multicolumn{7}{|l|}{ Foods, tonics and } \\
\hline digestive aids.. 3 & 108.7 & 121.0 & 102.0 & & & \\
\hline Foot preparations 9 & 108.9 & 112.9 & 93.8 & 112.9 & 112.9 & 112.9 \\
\hline \multicolumn{7}{|l|}{ Hair dressing prep- } \\
\hline arations & 99.7 & 107.6 & 91.5 & 113.7 & 134.4 & 88.8 \\
\hline Hospital supplies 1 & 100.0 & 100.0 & 100.0 & 100.0 & 100.0 & 100.0 \\
\hline Laxatives ........... 6 & 89.1 & 104.3 & 76.0 & 102.9 & 108.7 & 92.0 \\
\hline Manicure supplies 18 & 101.7 & 108.7 & 100.0 & 118.4 & 125.4 & 100.0 \\
\hline Mineral oils ....... 6 & 124.9 & 172.5 & 93.6 & 114.5 & 137.7 & 93.6 \\
\hline Ointments .......... 5 & 106.6 & 113.2 & 100.0 & 97.7 & 110.3 & 92.6 \\
\hline Patents ….......... 4 & 96.9 & 119.0 & 80.0 & 112.4 & 119.0 & 106.0 \\
\hline Salts $\ldots \ldots \ldots$ & 84.8 & 84.8 & 84.8 & 87.4 & 87.4 & 87.4 \\
\hline Salts, effervescent 7 & 93.4 & 111.1 & 77.5 & 102.9 & 111.1 & 88.8 \\
\hline Shaving supplies.. 15 & 100.1 & 113.8 & 87.9 & 116.2 & 136.3 & 100.0 \\
\hline Soaps $\ldots \ldots \ldots \ldots \ldots$ & 100.0 & 100.0 & 100.0 & 110.3 & 120.6 & 100.0 \\
\hline Sundries .............. 16 & 97.9 & 108.8 & 87.0 & 108.2 & 125.0 & 100.0 \\
\hline Suppositories ...... 2 & 105.9 & 111.7 & 100.0 & 120.0 & 120.0 & 120.0 \\
\hline Surgical supplies. 6 & 113.9 & 125.0 & 100.0 & 117.9 & 125.0 & 108.7 \\
\hline Totals $* \neq \quad \ldots . .203$ & 101.3 & 113.4 & 89.1 & 108.4 & 119.8 & 99.2 \\
\hline
\end{tabular}

* The Portland and Tacoma stores are units of an organization with headquarters in Oakland California. The quotations vere for the period prior to the passage of the 1935 Fair Trade laws in Oregon and Washington.

* Total percentages are aggregate averages.

Finally, there is the comparison of contractual prices within California with prices on identical items outside the state. Table IV shows the results of a study of prices on identical products in department stores in Portland, Oregon and Tacoma, Washington in relation to the California contractual prices. These prices were obtained through the head office of this firm in Oakland, California through which the Portland and Tacoma invoices were cleared. Since Fair Trade laws patterned after the California statute were not passed in Oregon ${ }^{84}$ and Washington until 1935, this study represents a comparison of California contractual

84 Oregon's 1935 statute repealed an earlier, ineffective one. 
prices with non-contractual prices on the Pacific Coast. The Portland prices averaged 101.3 per cent of California contractual prices; i.e., they were 1.3 per cent higher. The prices of the 203 items in Tacoma averaged 108.4 per cent of the Califormia contractual prices; i.e., they were 8.4 per cent higher. The range of variation within each group of products also is given in the table; in many instances there was a marked divergence between the low and high prices. Two conclusions seem proper to this comparison: (1) that the general average in Portland and Tacoma was so close to the California contractual prices to lead to the conclusion that the issuance of contracts had not influenced this general average in a significant fashion; (2) that particular prices were decidedly changed by the issuance of contracts, judging from the range of variation in the two northern cities. The likelihood is that the variation in prices in the same commodity class in Portland and Tacoma is traceable to local competitive factors which were not operative in the case of contractual prices.

A comparison was made between the contractual prices of fifty products in California with the going prices in twenty stores in Boston, Massachusetts. ${ }^{85}$ The arithmetic average of Boston prices was 108.4 per cent of California contractual prices: i.e., Boston prices were 8.4 per cent higher. The recommended prices of manufacturers in the case of Boston dealers averaged 19.8 per cent above the California contractual average. The Boston study points to conclusions similar to those drawn from the Portland and Tacoma studies, for the difference in the general average is slightly higher and there were also wide variations with respect to particular items.

Finally, an attempt was made to make a comparison with prices in Canada. ${ }^{86}$ However, the sample contained only 43 identical items and hence is large enough only for illustrative use. Interestingly enough, the arithmetic average of these 43 items was 102.9 per cent of California prices; i.e., 2.9 per cent higher. The range of variation, however, was wide, from 47.5 per cent to 145.1 per cent. The Canadian quotations were all on items protected in Canada. It is interesting that, although the average is so close to that of California under conditions of protection, there should be such a wide variation with respect to individual items. Apparently there are significant factors that make for variation in individual products between markets both in the case of protection as well as in its absence.

85 The writer is indebted to Robert B. Wentworth of Brookline, Mass., for the collection of Boston prices. The tabular summary is not reproduced here but may be found in MERRELI, GRETHER \& KITTELIE, op. cit. supra note 4, pp. 274-5.

86 A Canadian price list was furnished the writer by the courtesy of F. A. McGregor, Registrar, Combines Investigation ACT. 
TABLE V

MINIMUM RETAIL MARGINS ON PRODUCTS IN THE DRUG TRADE IN CALIFORNIA UNDER THE CALIFORNIA FAIR TRADE LAW, JULY, 1934

(Margins expressed as percentages of contractual prices)

\begin{tabular}{|c|c|c|c|c|}
\hline \multirow[b]{2}{*}{ Classes of products } & \multirow{2}{*}{$\begin{array}{l}\text { No. of } \\
\text { items }\end{array}$} & \multicolumn{2}{|c|}{ Range } & \multirow{2}{*}{$\begin{array}{c}\text { Arithmetic } \\
\text { average }\end{array}$} \\
\hline & & Low & High & \\
\hline Antiseptics & 62 & 10.3 & 70.0 & 29.07 \\
\hline 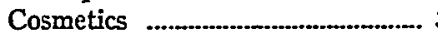 & 336 & 6.2 & 55.0 & 32.69 \\
\hline 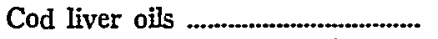 & 50 & 15.5 & 81.9 & 31.31 \\
\hline Cough and cold preparations...... & 24 & 7.3 & 50.0 & 34.20 \\
\hline 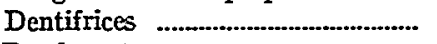 & 34 & 14.4 & 58.8 & 27.60 \\
\hline Deodorants & 14 & 13.8 & 33.4 & 25.26 \\
\hline Effervescent salts & 13 & 15.8 & 46.0 & 24.91 \\
\hline Eye preparations & 6 & 16.7 & 50.0 & 28.66 \\
\hline Foods, tonics, etc. & 55 & 16.4 & 40.0 & 27.90 \\
\hline 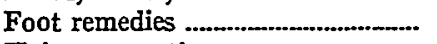 & 51 & 24.8 & 64.0 & 30.44 \\
\hline 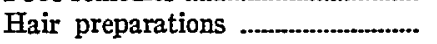 & 40 & 9.5 & 34.5 & 24.84 \\
\hline Hospital supplies & 37 & 14.7 & 61.0 & 36.05 \\
\hline Houseliold remedies ..................... & 13 & 11.8 & 48.7 & 33.30 \\
\hline Laxatives & 24 & 20.0 & 43.8 & 32.20 \\
\hline Liniments & 13 & 13.8 & 33.4 & 26.52 \\
\hline 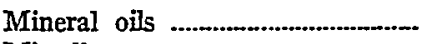 & 12 & 8.2 & 71.9 & 34.50 \\
\hline 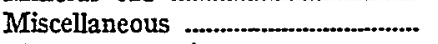 & 42 & 15.7 & 45.9 & 30.73 \\
\hline Nasal preparations & 6 & 20.6 & 33.3 & 30.60 \\
\hline 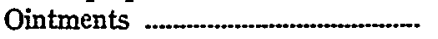 & 30 & 9.2 & 49.7 & 29.06 \\
\hline Patents & 43 & 18.8 & 55.3 & 31.70 \\
\hline 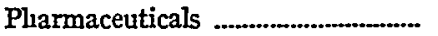 & 24 & 13.9 & 44.9 & 28.40 \\
\hline Pills, tablets and capsules............. & 43 & 13.0 & 63.2 & 31.20 \\
\hline Salts & 4 & 22.4 & 50.0 & 41.45 \\
\hline Shaving supplies & 58 & 5.1 & 62.4 & 22.60 \\
\hline Soaps & 18 & 17.0 & 65.2 & 31.94 \\
\hline Sundries & 112 & 13.1 & 58.5 & 42.24 \\
\hline Suppositories & 8 & 24.1 & 50.0 & 21.73 \\
\hline Tobacco & 44 & 13.0 & 26.9 & 18.92 \\
\hline 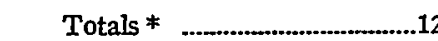 & 216 & 5.1 & 81.9 & 31.02 \\
\hline
\end{tabular}

- Total average is an aggregate average, not an average of the class averages.

The range is the lowest and highest of all the items, not of the class averages.

Table $\mathrm{V}$ portrays the mimimum retail margins on 1216 drug products under contract as of July, 1934. These 1216 items were all the products for which the writer was able to obtain wholesale quotations on the July, 1934 list of contractual items. The list as a whole contained only 1571 items; hence, the computation is large enough to be entirely representative. It should be noted that this computation is made only for the July, 1934 prices; the current list is considerably larger and it is possible that there have been some changes in margins.

There was a wide variation in margins allowed dealers under contract between firms, between products in the same class, and between commodity classes. The aggregate arithmetic average was 31.02 per 
cent. The lowest class average margin was for tobaccos, 18.92 per cent; the highest was on sundries, 42.24 per cent. The lowest individual margin was on a shaving supply, 5.1 per cent; the highest on a cod liver oil, 81.9 per cent. ${ }^{87}$ The range of variation shows many items sold far below an average operating margin figure; on the contrary many products are far above the typical dealer's average figure. Most significant is the total aggregate average of 31.02 per cent. It is rather surprising that so high an average should appear with a plan but recently introduced, for some manufacturers were loathe to raise prices sufficiently from their cut-rate levels to allow wide margins. Almost all the products with narrow margins had been reduced very low in cut-rate establishments - often below wholesale cost. The general average of 31.02 per cent just about approximates the rough figure that has been employed by the dealers. Commonly, dealers have mamtained that they needed about $33 \mathrm{I} / 3$ per cent of their sales for gross margin purposes. In the Northern California Drug Neres, November 15, 1935, there is published the result of a local cost survey. This survey shows a variation in total operating expenses in the various central and northern California areas from 28.32 per cent in the Salinas district to 37.75 per cent in Marin County. The average is given as 32.07 per cent. The figure for San Francisco and the East Bay area is 32.77 per cent. Thus, in terms of this survey, the contractual minimum margins already average enough to meet the expenses of the average dealer; more efficient and limited service dealers would be allowed a very nice basis for net profit-if they obtained their old volume. Also, since these margins were computed from the regular published wholesale list, dealers may receive free deals or extra discounts at times on some of the items.

It may be of interest to contrast these margins with those in Great Britain where resale price maintenance is old and well-established, having been put on an associational basis in 1896 when The Proprietary Articles Trade Association was founded. Table VI contains the class averages and totals for a random sample of 454 items taken from the 1933 published list of The Proprietary Articles Trade Association. In this case it was possible to list both minimum and maximum margins because special discounts, etc., were published. The aggregate average of minimum margins was 29.5 per cent; for maximum margins it was 32.4 per cent. A glance at the table will disclose a wide variation in margins between items and classes.

\footnotetext{
87 Readers will note that all margins are figured as percentages of contractual prices-not of wholesale prices.
} 
TABLE VI

RETAIL MARGINS FOR TWENTY-SIX CLASSES OF PRODUCTS IN THE DRUG AND CHEMICAL BUSINESS IN GREAT BRITAIN UNDER THE PROPRIETARY ARTICLES TRADE ASSOCIATION IN 1933

(Margins expressed as percentages of selling prices)

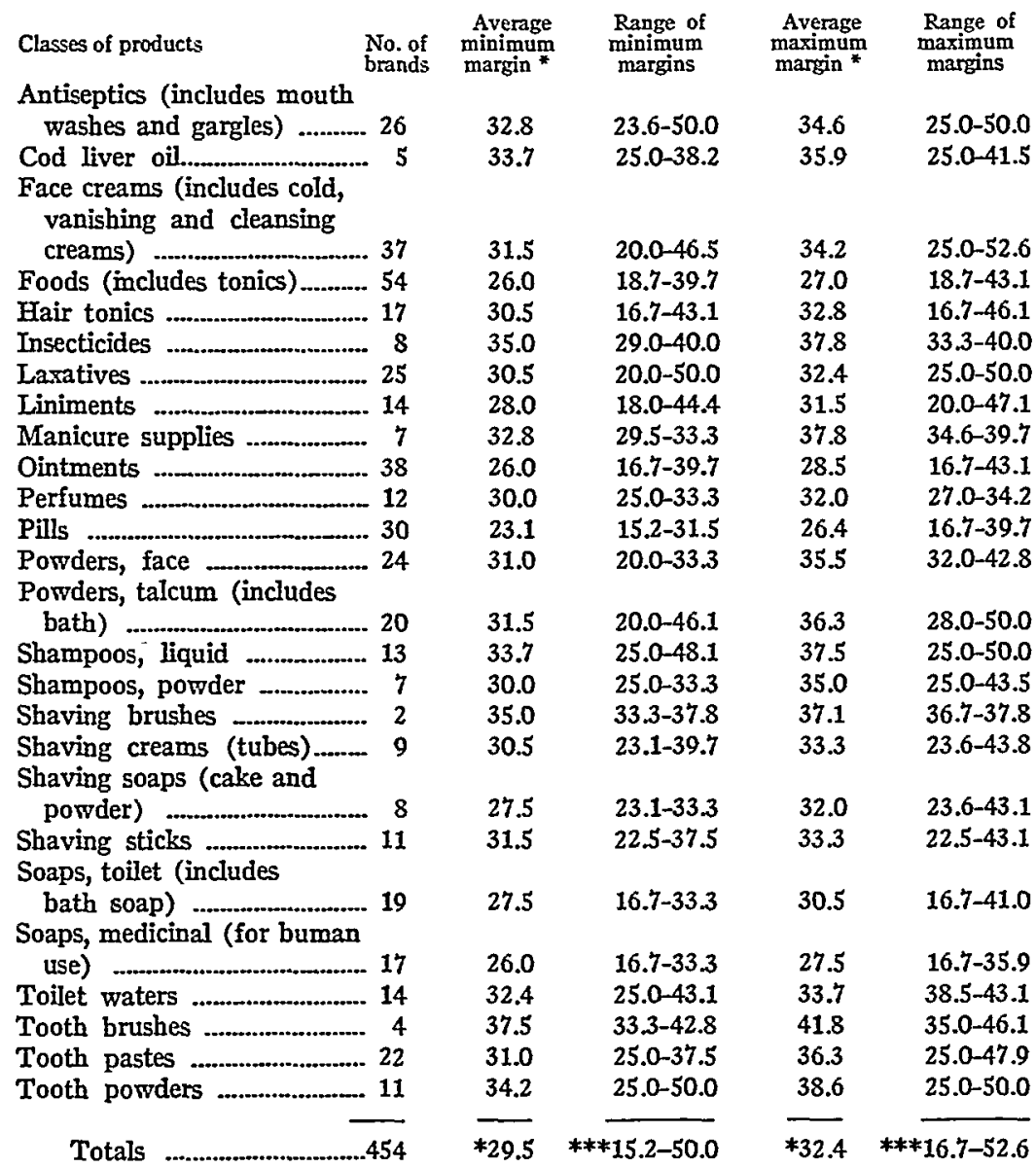

Arithmetic average.

* Total average is not an average of averages, but an aggregate average.

*** Not the range of average margins, but of individual margins in the total of 454 items.

Table VII represents a comparison of margins on 111 identical items in Great Britain and San Francisco. The aggregate average of minimum margins was 26.5 per cent for these 111 items in Great Britain; the aggregate maximum margin, 30.0 per cent. Since this computation was for the period before fair trade contracts were effective, it was impossible 


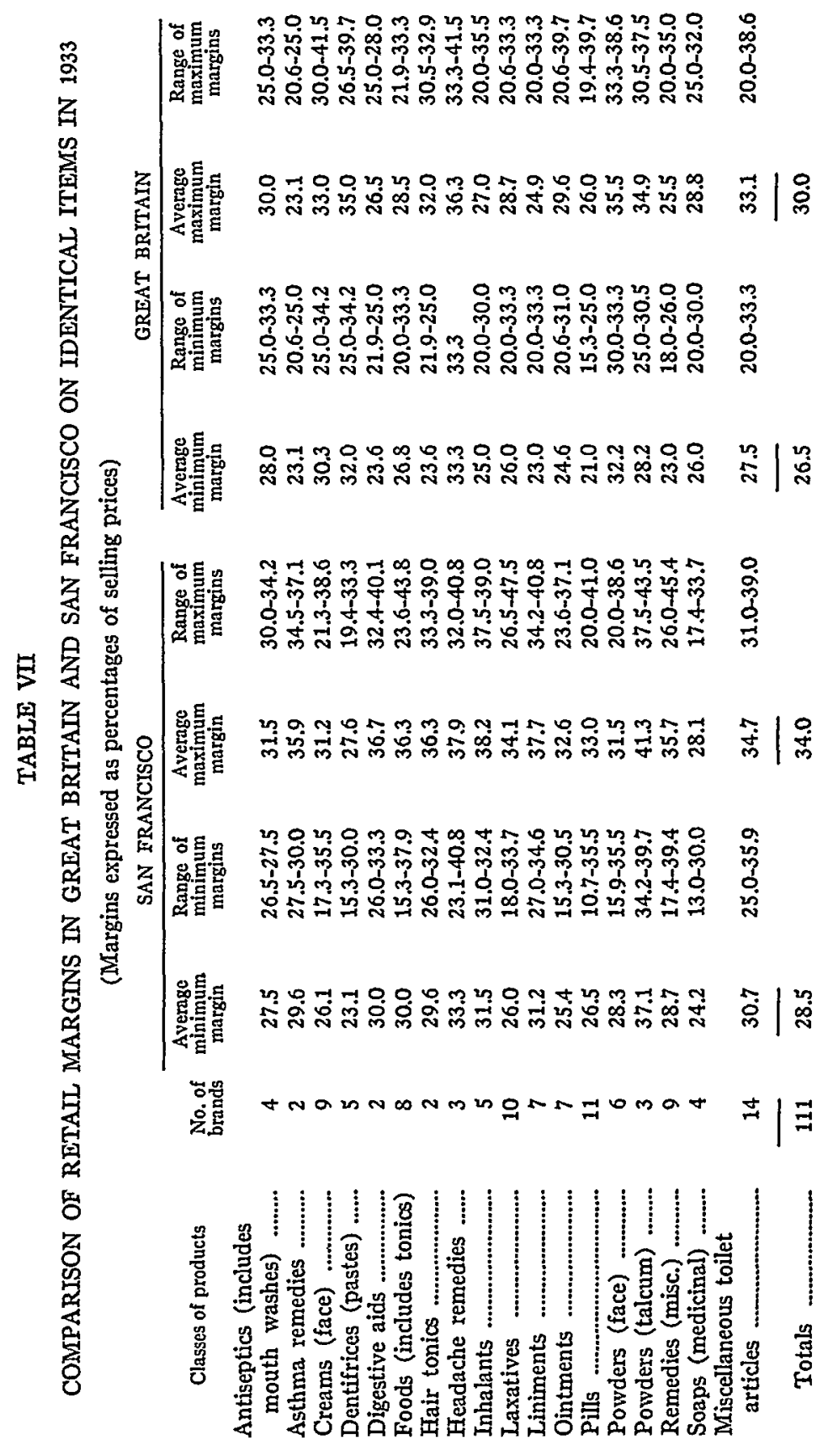


to contrast these margins with the specific contractual margins in San Francisco. Instead a comparison was made between the British margins and those that would have been received by San Francisco dealers if they had sold at the prices recommended by the local association and had purchased at the published wholesale prices. Figured on this basis, the total average of the San Francisco minimum margins was 28.5 per cent, and of the maximum margins, 34.0 per cent. That is, the San Francisco recomniended margins averaged from two to four per cent above those in Great Britain. On this basis, if proper, the actual average margins under contract on July 1, 1934 in San Francisco were approximately as one should expect. It is usually considered true that operating expenses in Great Britain are shightly lower than in the United States. ${ }^{88}$

\section{THE UNFAIR PRACTICES ACT}

Unlike the grocery trade, the druggists have placed their prime reliance upon the Fair Trade Act and have not pushed very much under the Unfair Practices Act. The reason for this difference is obvious. The Fair Trade Act is producing average margins for the trade, whereas to date the Unfair Practices Act has been used only to establish a floor under the market, based upon wholesale prices. It is mteresting that in the drug trade the N.R.A. code base is largely employed as it is in the grocery trade. In Los Angeles there is a drug bureau which is a policing and enforcing agency under both acts. It appears that two alternatives are open to the drug trade in its use of the Unfair Practices Act: (1) to attempt to raise the floor of the market above wholesale cost; (2) to leave it at this point and therefore attempt merely to hold all items that are not under contract from falling below this level. As long as manufacturers are sufficiently liberal with margins under contract there is no reason for the dealers to shift to the use of the Unfair Practices Act in the case of those items eligible for resale price control.

THE GENERAI APPIICABILITY OF THE FAIR TRADE ACT

To date in California the Fair Trade Act has been employed in only a small number of lines: drugs, wines and liquors, photographic supplies, cigars, stationery and office supplies, radio and grocery. There has been some discussion and slight effort at operation in a number of other lines such as beer, household furnishings, and hardware. However, the inajority of goods sold at retail are not protected by fair trade contracts. This absence of contractual control is neither accidental nor entirely traceable to the brevity of the period since the obtaining of legal rights. In the first

s8 Tables VI and VII are reproduced from the writer's study, GreTarer, op. cit. supra note 10 . While im Great Britain, the writer saw no thoroughgoing studies of operating expenses in the retail drug business. A small study that he had access to showed gross operating expenses of about 29-30 per cent. 
place, under the wording of the law, protection is open only to commodities which bear the trade-mark, brand or name of the producer or owner. This limitation immediately removes probably the bulk of goods sold at retail from the possibilities of control, for they either do not bear the mark of the producer, or when they are so identified, the manufacturer or other producer has no interest in them after title has been transferred. For instance, three-fourths or more of the volume of a department store would fall outside the contractual pale. In the second place, there are very serious resistances to resale price control within the field of trade-marked goods, as was noted in the analysis of the grocery trade. Since the summary of the resistances in the grocery trade is applicable in other trades, they will not be repeated at this point. The grocery trade has focused within it practically all of the serious resisting influences. These same resistances show themselves in a variable fashion in all trades. The dry goods trade, for instance, is perhaps even more difficult than the grocery trade. Few trades are as well adapted as the drug trade for this type of vertical price control. Resale price control under the California Fair Trade Act cannot become a general procedure in the state but must remain limited to the minority of products in retail stores at present or as long as conditions remain similar to those of this period. The writer's opinion at this point is based not only upon the California experience to date, but upon British experience where the systein is mature. ${ }^{80}$

THE GENERAI APPLICABILITY OF THE UNFAIR PRACTICES ACT

The horizontal procedure under the Unfair Practices Act may develop possibilities for wider, perhaps, even general application, in contrast to the relatively limited possibilities of the Fair Trade Act. The strength of the Unfair Practices Act is that action under it need not wait upon the initiative of manufacturers or distributors at the apex of the distributive pyramid but may arise at any level, and that it is not limited merely to trade-marked, identified goods. Its possibilities for general use, however, are definitely limited by a number of terminological difficulties which must, for the time being, wait for further court interpretation and trade experience. In the small number of months since the 1935 Act went into effect it has aroused a great deal of interest and discussion. Numerous rumors of action under it have constantly been coming to the attention of the writer. Usually these rumors when checked had their source merely in discussion in the trade and not in formal activity. The grocery and drug trades, which were discussed above, and the wholesale tobacco trade in southern California to date are the chief fields where

89 Cf. Gretran, op. cit. supra note 10, pp. 301-311 and 326-334. On pp. 292-300 there is a classification of the chief resistances to price maintenance in Great Britain. 
operation under the act has gone past the stage of discussion into organized expression. The amount of interest that is being displayed in other lines presages a great amount of activity if the way is cleared.

The sales below cost provisions of the act are its core and have aroused the general interest in its possibilities. Hence, the discussion here will be centered upon them. The earlier discussion recalls that these provisions, as well as the others having to do with price discrimination, etc., are effective only when the practices of the alleged violator are for the purpose of injuring or destroying competition. Obviously, intent and motive are always difficult to establish and this burden of proof will remain as a powerful barrier to the use of the act unless a fairly definite, relatively routine and standardized type of evidence is taken as proof of intent. Hence, the issue is whether there is anything in the cost provisions which allows this interpretation and procedure. Cost is defined in production to include "the cost of raw unaterials, labor and all overhead expenses;" in distribution, as "invoice or replacement cost, whichever is lower, plus the cost of doing business." It will be recalled that the costs of doing business are enumerated in detail. However, among the exceptions to the cost provisions is the significant one that a given vendor may sell below his own cost point "in an endeavor made in good faith to meet the legal prices of a competitor." Thus immediately it is clear that the act may affect the price level in a given area only by making the costs of the most efficient competitor the floor of the market.

There is, however, another and more serious complicating factor. From the wording of the act it is not clear whether the costs that must be covered are the average costs of the vendor or the particular costs involved in the sale of a given article. The average mark-up of a given firm is merely an average of particular marking rates above and below it. Individual mark-ups should and often do vary with the particular expenses, losses, markdowns, etc., attached to particular items. It would be revolutionary to say the least, as well as uneconomical and inefficient, to set up uniforn average marking rates on all items in a given assembly. It is granted, of course, that traditional, customary and other irrational factors (especially inertia) often do produce marking rates unrelated to the specific cost factors involved. The use of an average figure under the act would lend legal sanction to the factors making for dis-economy. However, assuming that the courts should accept this interpretation then the simple, routine procedure would be to accept the average cost of bona fide dealers who are specialists in handling this particular product and who have the lowest costs in the given locality, as the base for regulation. Among the difficult problems which this average procedure 
would not settle are particularly the following: (1) how should the costs and prices of full service operators be computed in relation to limited service firms? (2) how should the costs and prices of firms outside this field who stock the particular item as a side line be computed? Actually, few markets are homogeneous; instead they normally consist of a series of segments in which there are variable and different competitive and monopolistic elements with some degree of competition running across and between the segments. Normally in retail markets there is no single competitive price for the market as a whole, but levels of competitive prices for the various segments. For instance, one of the local voluntary merchandising groups in the grocery trade had seven different price levels froin which members made a selection for their direct mail advertising. Furthermore, within each market there is always some nibblimg on the part of dealers who are not directly in it, but influence it insofar as they stock the items as supplementary or side lines. Reasonably and economically, the application of the average cost conception should involve an attempt to classify the competitors in a market according to the various levels of operation. Much as this is to be desired, it is safe to predict that it would lead primarily to legerdemain, quibbling and delay in the courts. The only reasonable alternative that would allow large scale action under the act is the acceptance as the base of operation, the average costs of the most efficient, limited-service vendors in the market of the type through which the majority of this class of product is sold. This base would merely establish a floor to the market on this average basis of computation and all of the other dealers would have costs above this base price.

Froin the standpoint of economy and efficiency the computation should be not upon an average basis but upon a particular cost basis; that is, costs should be computed in relation to the particular and variable expenses attached to a given item. No healthier influence could be thrown into California business than the stressing of individual, rather than average costs. Following this procedure the effective costs would be the particular costs either of the most efficient limited-service dealer (assuming no attempt were made to classify the dealers in the market) of the type through which the bulk of goods is sold, or of any dealer. The wording of the exception in which a dealer may meet legal competition supports the latter conclusion. In either case the outcome is merely again the establishing of a floor to the market but derived from particular rather than average cost calculations. To the writer it appears that this base might be the costs of the most efficient firm selling the product as a side line, and hence would normally involve only a relatively small margin compared with the needs of the majority of the trade. As 
far as the courts go, this procedure might also lead to a tremendous amount of legerdemam, for any attempt at the calculation of particular costs necessarily involves a residual element of arbitrary allocation in which there may be wide differences of opinion. ${ }^{90}$

In view of the difficulties sketched above it appears that the only way in which there may be a wide-spread, organized development under the Unfair Practices Act is for the courts to accept invoice or replacement cost, whichever is lower, or this amount plus a relatively low mark-up (as in the stop loss provision of the codes) as the standardized basis of operation. Theoretically, the writer would prefer to see this figure established out of an attempt to calculate particular costs. However, no matter how calculated, it would be merely a loss limitation provision establishing a bottom to the market and not a means of guaranteeing margins or fixing prices. If at the same time the courts accept evidence of sales below this base figure as an indication of intent and hence as a violation, then it seems low loss limitation floors might be placed under a large number of California markets. The selling effect of this procedure would be the abolition of the deeply cut forms of loss leader selling without producing price fixing.

Thus, the above interpretation supports the procedure in the grocery trade with its six per cent mark-up as the market floor, or in drugs, where wholesale cost has been used, or in the wholesale tobacco trade in Los Angeles where four per cent and three per cent mark-ups are employed. Any attempt to use the act to enforce full average margins should lead ultimately to failure both legally and economically. Unfortunately, these policies already in effect and which offer an opportunity for wide adoption do not fulfill the literal wording of the law. Certaimly, using merchandise cost as the base cannot be justified by the literal wording which calls for the addition of overhead or operating expenses to overhead costs. However, there seems to be no reason why the courts could not accept sales below merchandise or replacement cost or such cost plus a small mark-up that represents merely a loss limitation provision, as evidence of intent to injure competition. In fact, this on the whole appears to be the interpretation to date. On this basis

90 The particular versus average costs issue was discussed by a Berkeley market in an advertisement in the Berkeley Shopping News, Nov. 8, 1935. When this market was haled into court on a complaint that it was selling below cost, it raised the following pertinent questions in its advertisement: "What is the cost of doing business on a particular article singled out of the thousands of articles that the

Markets handle? Is it the average? Does the same mimimum mark-up apply to fresh meats, to fresh fruits and vegetables, to dehicatessen and to dry groceries? Does it apply to bread, milk, eggs, butter, flour and other commodities which every family consumes daily, as well as to the foods which are not necessary to the average houschold?" 
operation under the act might be fairly well routinized; so much so, that there would be little need for recourse to the courts. Court action, once this principle were establisherd, would be essential primarily in those instances where a trade wished to raise the floor of the market above this minimum point. It is this type of attempt that might readily produce confusion in the court because of the factors discussed above.

Another barrier to the wider use of the Unfair Practices Act appears to have been removed at least potentially. Bringing an action under the act is expensive - too much so, in fact, for the ordinary dealer. However, as was noted in the description of the general character of the act, trade associations may bring action. But even trade associations have their financial difficulties. Throughout California, district attorneys have been assisting interested members of the trade by addressing meetings in the trades and explaining the nature of the act. In May, 1936, Attorney General U. S. Webb wrote an opinion to the effect that district attorneys nnay prosecute violators of the act under section 3369 of the Civil Code. 91 This 1933 amendment, section 3369 of the Civil Code, states that "Actions for injunction under this section may be prosecuted by the Attorney General or any district attorney in this State in the name of the people of the State of California...." Since acts of unfair competition are the acts specifically mentioned in this amendment, it appears that violators of the practices defined in the Unfair Practices Act might be prosecuted by the district attorney. Hence, the financial obstacle to action in courts may be greatly reduced. One may reasonably expect that great pressure will be placed on the various district attorneys for action under the act.

THE GENERAL ECONOMIC EFFECTS OF THE UNFAIR PRACTICES ACT

Unlike the Fair Trade Act, it is impossible as yet to make an adequate collection of data to indicate the results of operation under the Unfair Practices Act. On the basis of the nature of the act and the interpretation of it as given, it is possible to arrive at a number of reasonable, tentative conclusions. Its provisions prohibiting price discrimination and the giving of secret rebates, allowances, and unearned discounts, are proper regulations of trade practices. Large scale distributive organizations, especially chain systems, have a number of advantages that are related merely to their size and organizational form and are not necessarily linked with internal operating economies. One of these is the ability to sell at a loss in one location in order to gaip a competitive advantage, in the meantime absorbing this loss by profits made from

91 Cal. Stats. 1933, p. 2482. Attorney General Webb's opinion is quoted in the California Retail Grocers' Advocate, May 22, 1936, p. 8. 
higher prices in other locations. Clearly the individual dealer is handicapped, for all of his eggs are in the one basket. Likewise, the specialist in one line is handicapped when a large concern with a wider assembly selects his particular product for loss leader purposes. The anti-discrimination prohibitions of the Unfair Practices Act curb the first type of discrimination; the sales below cost provisions to some extent curb the latter. The prohibition of price discrimination between locations (makmg due allowance for differences in quality, material costs, and transport costs) is entirely in the interest of fair and equitable conditions of competition. The prohibition of loss leaders in general will be discussed below in more detail. The prohibition of unearned discounts likewise is eminently proper. From the standpoint of efficiency, discounts should be a measure of differences in the cost of producing, selling, delivering, etc., in the various size lots. When they range above or below this earned basis they impede the full effect of forces making for economy in operation.

Assuming that the writer's interpretation is correct that the sales below cost provisions of the act can be employed widely only as loss limitation devices, then the fundamental issue of the Unfair Practices Act is that of the economic consequences of this policy. The prime surface effect of loss limitation devices within the trades is to limit the range of price variation by raising prices below this floor to its level. That is, when loss limitation devices are so low that adequate margins to cover expenses of operation are given to no one, then they merely remove a portion of the depth of loss leader selling. Space does not allow a thorough analysis of the theoretical aspects of loss leader selling. Specialists in given commodity limes are liit worst in loss leader competition when their larger competitors, for example, department stores or mail order stores, use their specialty items as bait to attract patrons to other lines and departments. In so far as a curb upon loss leader selling removes this handicap from the specialists it is of the same quality as the anti-discrimmation provision, and appears eminently fair. From the standpoint of the users of loss-leader tactics, however, there are good reasons for justifying them if they produce volume better than an equivalent expenditure in other directions, for example, in advertising. Often the issue here finally resolves itself into a clash of classes of enterprise that are so different from an organizational standpoint as to make close comparisons impossible. In fact, the issue finally becomes a question of whether certain loss leader practices should be prohibited in the interests of protecting small scale business even though they are "good business" from the standpoint of the larger scale users. Obviously, they are good business for the larger firms if their attracting power, because of immediate or indirect joint demand factors, produces an additional 
volume of sales beyond the losses taken upon them. Too, in case these larger firms then show lower general operating expenses than their smaller competitors, it seems possible, from an economic point of view, to accept them as far as the coinmunity is concerned. When this condition exists, then their prohibition must be defended on general social and not upon strictly economic grounds. That is, small, specialized dealers like small farmers, perhaps should be subsidized because that type of society is deemed preferable. ${ }^{92}$

The impact of the below cost provisions of the Unfair Practices Act would not so much destroy loss leader selling as it would moderate it in respect to given items. Price cutting firms, presumably to gain an equivalent result, would be forced to cut a wide array of goods narrowly as opposed to cutting a small number of items deeply. That is, a readjustment of marking rates would be forced with a smaller dispersion. One important aspect of this control is that it is then possible to a greater extent for small dealers and specialists to use the same tactics because of the known depth of the market. Without such controls, small dealers and specialists often feel that they cannot and dare not meet loss leader prices because they cannot afford to plunge in as deeply as their larger, general line competitors. Hence they stay out and hope that the loss of volume may not be too great.

$A$ priori loss limitation devices should bolster the position of smaller dealers and specialty firms. This effect is abetted by the administrative fact that it is much easier to obtain evidence against, and to control, large scale operators whose selling activities must be more highly public and open.

From the standpoint of the public as consumers it appears that loss limitation devices are harmful only to the group that had, and took, the time to shop for loss leaders. And then, perhaps, only in the purchase of those particular items. On the average the consuming public probably gains, for the general level of prices should be pulled slightly downward, in so far as smaller dealers now are willing and able to join in price cutting. Evidence is scarce on this point; the best data are found in a study by $R$. G. Gettell of the effects of the loss limitation provision in the drug code upon the prices of twelve drug products in 108 Manhattan drug stores. Mr. Gettell's study showed an aggregate decline in retail prices of 5.1 per cent for these items in the 108 stores after the loss limitation provision went into effect..$^{93}$ Hence, from the standpoint of

92 For a mathematical treatment of the loss leader problem see Roos, DxNAMIC Econonncs (1934). However, Roos' analysis is limited to the use of loss leaders in strict joint demand relationships. Often there is only an indirect effect, difficult if not impossible to measure, upon other items.

93 See Merreli, GreTHer \& KITTELIE, op. cit. supra note 4, pp. 134-149. 
these dealers the problem of whether a loss limitation provision is worth the effort depends upon whether the slight decline of their prices is offset by an increase in sales gained from large-scale competitors. ${ }^{94}$

The proper conclusions with respect to the general economic and trade effects of the Unfair Practices Act are: (1) it should not inake for higher prices, instead it may often make for a slight decline in the general price level; (2) it should improve the competitive position of smaller dealers slightly; (3) insofar as the above effects are produced it will have assisted to some extent in the stabilization of prices, for the range of variation of prices tends to be less after the floor is placed under the market, both because of the raising of the deeply cut prices and the lowering of the general level. Consumers, on the whole, have nothing to fear from these effects; instead, in general they should gain slightly. Also, these results are not sufficiently significant to justify the faith of legislators and many members of the trade that the ills of depressed markets were to be removed under the act. Conversely, if the Unfair Practices Act had provided the basis for a significant increase in the retail price level, and a considerable expansion of unargins, and for stabilization at that level, then its general effects would have run counter to the interests of the community, if other things had remained equal, in the depression markets.

THE GENERAL ECONOMIIC EFFECTS OF RESALE PRICE CONTROL UNDER

TEIE FAIR TRADE ACT

The Fair Trade Act, obviously, produces much inore consequential results in those trades in which it can be employed than does the Unfair Practices Act. Unlike the Unfair Practices Act, it makes possible the establishing of uniform prices in the market irrespective of services costs, efficiency or type of outlet. Further, it is not merely a loss limitation device, but allows the guaranteemg of margins to dealers.

The first general economic problem to be discussed is the effect of resale price control under the act upon the competitive position of the various factors in the market. Does resale price control improve or harm the access to and position in the market of the various classes of dealers, manufacturers and distributors? Unfortunately, the thorough answering of this question involves knowledge of certain long-run effects for which the brief California experience is not adequate. ${ }^{95}$ Hence, the comments that follow are necessarily tentative.

94 Ibid. Part IV of chapter 7 contains evidence that some small druggists did not receive a compensatory increase in sales volume.

95 British experience is enlightening since the system there is mature. See GRETHER, op. cit. supra note 10, pp. 301-25. 
It seems that there can be little reason to dispute the assumption that effective resale price control would throw a larger proportion of the volume of business of nationally advertised proprietaries and of staple, standard goods to the smaller, independent dealers. This is the faith that lies behind the fervor of these dealers; the general evidence justifies the behef to date. In more prosperous times this result should be even more marked. Conversely, the competitive position of the lower class, lower cost, cut-rate institutions should be weaker with respect to the sale of nationally advertised staple goods. This would be a serious blow because their merchandising program is based upon the quick turnover of fast selling items at prices below the market. Evidence is still inconclusive, but it appears that these institutions have been losing busi-ness on these staple, controlled items. However, the final conclusion cannot be foreseen as yet because these institutions have four competitive devices which are being employed to strengthen their position: (1) pushing the standard lines that are not controlled; (2) featuring lines that are not well known; (3) pushing their own or other private brands; (4) using non-drug merchandise for loss leader purposes. The assumption of the organized retail druggists is that these devices will not recoup the losses on controlled items; hence, there will have been a relative decline in the competitive position of cut-rate firms. It is impossible to predict the outcome as yet, especially because of the absence of normal market conditions. Some of the stronger cut-rate houses feel confident that they will be able to establish their own private brands if necessary. A number of these firms have already built a considerable volume under their own labels. Factors of mertia must also be considered; a large portion of the business attached to these stores may be expected to adhere to them for a considerable period, perhaps long enough to become accustomed to the wider use of private brands.

It seens that the well established chain systems are in the strongest position to capitalize upon resale price control. By selling controlled goods at minimun prices they are able to build a reputation for selling these items at lowest prices; in addition, they have the reputation, prestige and a large enough number of outlets for pushing their own private lines. As large institutions they are able to employ mass advertising media and are able to establish their own lines much more effectively than individual, small dealers.

The effects upon department stores should vary with the class of business and the type of chentele. It is doubtful whether the volume of sales of the upper middle class stores will be greatly affected. The lower class stores have the same probleins of the cut-rate drug stores; that is, they are forced to push non-controlled goods and their own brands. In 
addition, they are in a strong position to feature non-drug merchandise for loss leader purposes. A well-established department store should be able to build its own brands more effectively than the independent specialists.

From the standpoint of the welfare of the great mass of small dealers there is an intrinsic threat to the system of resale price control in its attraction to new dealers if it matures into a going mechanism. Guaranteed margins and stabilized conditions are ideal magnets for new enterprises. Eventually, the trade will be forced to grapple with this problem unless professional and legal requirements alone are sufficient to limit numbers. If no adequate control of numbers in the business is developed (or is mherent in professional requirements) then the whole plan may eventually topple under its own weight. The writer feels that the smaller dealers are over-optimistic concerning the potential long-run assistance that they will receive from resale price maintenance per se in competition with their larger scale competitors. Their chief gain, competitively speaking, should be at the expense of smaller cut rate institutions.

The effects upon wholesalers are difficult to foresee. In so far as volume is thrown to smaller dealers they should gain unless the enforcement of resale price control leads to a larger amount of direct selling. From this standpoint, it is decidedly to the interest of wholesalers to become the policing agencies of manufacturers under their own and omnibus contracts. The problem becomes complicated by wholesale private brand merchandise. Wholesalers are in a strong position because many dealers are tied closely to them under credit controls. The repercussions of a major effort to build private labels cannot be known as yet. For the time being wholesalers seem to have benefited by the improvement of the status of smaller dealers and by a reduction of direct selling.

From the standpoint of the manufacturers of well-known advertised goods the problem is essentially two fold: (1) the effects upon their volume in relation to private brands; (2) the effects upon their profit margins. The results with respect to both volume of sales and profit margins are bound to be variable depending upon the individual circumstances surrounding each firm. The private brand threat in the case of well-intrenched national brands is probably not nearly so serious as the threat of boycott on the part of organized, independent dealers in the immediate situation. Group action on the part of the mass of dealers has introduced an entirely new element into the problem in contrast to the earlier period when such organized action was absent. From a longrun point of view, the private brand threat without doubt would be serious for many firms.

The impact of the force of the action of organized dealers is exceed- 
ingly significant from the standpoint of economic theory. It will be recalled that the privileges of the California Fair Trade Act can be enjoyed only by producers of trade-marked commodities "in fair and open competition with commodities in the same general class." This statement in the law suggests two presumptions: (1) that monopoly and fair and open competition are at opposite poles; (2) that the presence of monopoly would deny the privileges of the statute. As a matter of fact, "fair and opon competition" is possible of precise definition only in terms highly abstract and unrealistic. Conversely, an adequate definition of monopoly becomes equally abstract and unrealistic, except for logical purposes. In the great majority of pricing situations there are intermingled in a highly variable and complicated fashion elements of competition and monopoly; their complex, necessarily partaking of both,--is strictly speaking neither. In the retail business, dealers possess elements of monopoly in their locations, reputations, goodwill, personality, trade connections and in the control of the buying habits of their customers, as well as in miscellaneous special merchandising services. The manufacturers of trade-marked goods possess monopoly rights and powers in their trade marks, formulae, reputations and goodwill, personalities and abilities of executives, trade connections, deeply rooted trade customs and habits built about them, and in the business strategy that these elements make possible. Time and space do not here allow grappling with the horizontal aspects of these monopoly powers; i.e., their relative weight and influence in relation to competitors in the same class and on the same level. But it is highly important that the significance vertically be discussed, for the relative freedom of a given manufacturer of trademarked goods from the pressure of simple competition (i.e., the competition set up in economic logic) has significant repercussions upon the distribution of the consumer's dollar between the imtermediaries, vertically speaking. Manufacturers with large monopoly power have demonstrated in the past that they are able to obtain and maintain the distribution of their products without rewardimg dealers at all (at times) or without compensation proportionate to the expense involved. Resale price maintenance fostered by organized dealers as in California, replaced the individual dealer by a bargaining group which has demonstrated strength somewhat equivalent to that of the manufacturer. The impact of this new force brought into vertical relations is to force either a re-apportionment of the consumer's dollar more favorable to dealers or an increase in prices to consumers. Both influences are operative; it would be a highly significant price study that would develop a measure of the degree of each.

Finally, there is the problem of the effects upon consumers. The 
issue here is one of the prices of drug products in relation to quality of goods and services under conditions of resale price control in contrast with those when such control is absent. It is clear that the segmenting of the market, discussed above, creates not merely one issue but as many as there are market levels. If consumers were always aware of the differences in quality and in service and calculated rationally, then much of the demand for resale price maintenance would disappear for they would appreciate that there inust be price differences arising out of service, convenience, quality and other differences. From the standpoint of economic theory, what appear to be identical products are not such when sold with variable service, convenience, reputation, etc., elements attached to them. The small, independent druggist argues that release from some of the rigors of price competition allows him to improve the quality of the miscellaneous services, especially those of a professional sort, involved in the sale of goods. The volume of sales in neighborhood drug stores is evidence that their combination of professional service and convenience in connection with drug products is valued highly by many consumers.

Without doubt those consumers who wish to buy standard drug products with a minimum of professional attention and merchandising services are harmed by resale price maintenance, except in so far as they are able to obtain an equivalent quality under private labels. Even so, they may not obtain an equivalent income of enjoyments, because of the absence of the important element of reputation. All of the price studies above established the basis for the conclusion that that portion of the public which has purchased standard goods from cut-rate institutions would suffer by control. Beyond this, there is the imponderable question of the quality of the other goods which are often purchased by these customers.

Conversely, it appears that the relative position of consumers who patronize smaller, independent drug stores, especially neighborhood stores, is little changed, perhaps slightly improved under resale price control, for they continue to purchase at prices no higher, perhaps even slightly lower than previously.

Whether contractual prices are, and remain, lower than the former prices in the great mass of independent stores is partly a matter of the width of the margins given dealers. Table V shows that the 1934 margins already averaged 31.02 per cent of contractual prices. Since unargims were this wide so early in the plan it might be assumed that there would be a tendency for them to widen as manufacturers and distributors competed for the favor of dealers. However, the issue is not so simple, for manufacturers realize that there is a connection between the price level 
and volume of sales and will resist both an increase in prices and a reduction of their own margins. The writer's prediction is (based upon British experience) that some margins will widen for a brief period and hence the general average will expand slightly; but that the long run tendency (if the system matures) will be toward a narrowing of margins.

Whether consumer prices rise, remain constant, or fall is not entirely a matter of the amount of dealer margins, but is also related to the distribution of the consumer's price between the various market intermediaries. Much of retail pricing can no longer be analyzed merely on the retail plane; allowances must be made for vertical bargaining influences. Likewise, smce monopoly elements adhere to trade marked goods the selling prices of manufacturers bear no necessary relation to their production and marketing costs. This, of course, is merely a technical way of stating what is commonplace knowledge in this field. The essence of resale price control in the drug trade in California is that the vertical price factors become affected by some amount of organized bargainmg between retailers and manufacturers. In this pricing situation, ordinary competitive price theory is madequate. The tools of analysis essential to grappling with this problem are only now being sharpened by economists..$^{96}$ This problem is particularly complicated because it involves the focusing both of horizontal and vertical forces of monopolistic competition. There is no basis in price theory to predict the exact outcome. It is possible that frequently the outcome represents a compromise in which manufacturers are forced to take smaller gross margins to compensate for the guaranteed margins to dealers. When this happens, the prices to consumers may not be increased. The danger is that manufacturers will attempt to hold their margins and obtain the guaranteed dealer margins by increasing prices to consumers. ${ }^{97}$ In such an event there is the resistance of the horizontal forces of the prices of competing products.

In conclusion one impact of the vertical influence of resale price control upon horizontal price fixing forces should be examined. The various price studies which compared prices of California contractual items with prices on the identical goods outside the state demonstrated that the level was not significantly different but that there were wide variations for individual items. This result merely means that the arbitrary margins established by manufacturers with or without bargaining with organized dealers, although they approximate the average prior

96 Lay readers will find readiest access to these newer stresses in economic theory in Chairierdin, The Theory of Monopolistic Competition (1933) and Roninson, The Theory of IMPERfect CoMpetition (1933).

97 ChamberLIN, op. cit. supra note 96 , at 108 , states that " a liberal margin to the dealer is usually more important than a low price to the consumer." 
situation, quite largely destroy or inhibit the play of the local horizontal supply and demand forces bearing upon any given product. Thus a general stabilization is at the expense of flexibility in individual pricing in each market. From the standpoint of consumers (except those buying from cut-rate stores) the significance of this condition is that in general they are no worse off, but any individual consumer in the purchase of any individual article may be harmed or may reap an advantage.

\section{GENERAI OBSERVATION}

It may not be beyond the legitimate bounds of this paper to suggest what appears to be a more adequate public policy for dealing with the problems of unfair price practices than the methods in the two acts analyzed in this paper. What is needed is a flexible procedure adaptable to the variable factors in each trade instead of broad general policies that cannot be related to the innumerable peculiar characteristics of the various classes of enterprise. Likewise the ideal policy would not allow for establishing uniformities and rigidities in price structures, for these impede the flexible adjustment of supply and demand factors. Among the generalized procedures, the loss linitation devices which the Unfair Practices Act makes possible have much to be said for them, for they do not allow for definite price fixing but merely narrow the range of variation in price cutting by removing some of the depth of loss leader selling and by lowering the price level slightly. Conversely, the procedure of the Fair Trade Act cannot be defended as a generalized scheme for (1) it is not applicable to the majority of goods; (2) when it is, it allows the establishmg of an undue uniformity and rigidity in the price structure.

A flexible program of regulation adaptable to the variable elements between trades might be developed in two ways: (1) through regulating commissions (as the Federal Trade Commission in inter-state trade and similar state commissions) empowered to take action against price cuttimg in unfair competition; or (2) through the establishing of agencies in the various industries and trades with governmental supervision and with governmental representation, empowered to take action against price cutting in unfair competition as well as other unfair methods.

In this country there is a background of experience for both types of procedure. Although the latter smacks strongly of the late lamented and castigated N.R.A., the writer feels it is a fundanental portion of proper public policy. Likewise, it derives readily from the American traditions and attitudes. Under such a procedure a given industry or trade should have a double burden upon it in setting up its taboo list of unfair price practices: (1) it must achieve agreement among the majority of 
its members; (2) it must be able to demonstrate the uneconomical and unfair nature of the alleged unfair price practice. If an industry and trade can neither agree upon what is considered unfair, nor present evidence concerning the ill-effects of the practice, then it is reasonably certain that the problem is not uneconomically acute. This suggestion is not intended to convey the idea that all other regulating agencies such as the Federal Trade Commission should be removed from this sphere of regulation. A central body would always be necessary to take action in those instances where the trade agencies are incapable or unwilling to act. However, a large portion of regulation could be transferred to the various industrial and trade agencies where it should eventually develop into an expeditious and flexible mechanism for removing the type of practices which provides much of the basis for the cry for price control.

Ewald T. Grether.

University of CaItfornia,

Berketex, Catifornia. 